\title{
Medine Harem Bölgesinin Tespiti: Eleştiriler Bağlamında Bir Buhârî Rivayetinin Serüveni
}

\author{
Tahir Ayas*
}

\begin{abstract}
Bazı hadislerde Mekke gibi Medine’nin de harem bölgesi olduğundan bahsedilmektedir. Hz. Alỉnin kılıcının kınında muhafaza ettiği bildirilen sahîfede yer alan rivayette, Medine’nin harem bölgesinin sınırları, şehrin kuzey ve güneyinde bulunan Âir (Ayr) ve Sevr dağları olarak tespit edilmiştir. Ancak bu dağların, özellikle Sevr dağının Medine'de mevcudiyetinin bilinmediği gerekçesiyle erken dönemden itibaren rivayete eleştiriler yöneltilmiş, hadisin bu kısmında bir vehim olduğu ileri sürülmüştür. Bunun neticesinde söz konusu hadisi nakleden râvilerin ve eserine alan musanniflerin, tenkitlerin etkisinde kalarak hadisin ilgili kısmı üzerinde birtakım tasarruflarda bulundukları ileri sürülmüştür. Eleştirilerin merkezinde ise Buhârî ve eseri el-Câmiu's-sahîh yer almaktadır. Bu makale Medine’nin harem sınırlarını Ayr ve Sevr olarak belirten rivayetin râvilerine ve hadise eserinde yer veren Buhârîye yöneltilmiş tenkitleri tahlil edip, başlangıçta rivayete yöneltilmiş eleştirilerin hadisin metni üzerindeki yansımalarını tespit etmeyi hedeflemektedir. Böylece hadis metinlerinde meydana gelmiş kasıtlı kasıtsız pek çok tasarruf örneğinin yanında, metne yönelik eleştiriler neticesinde meydana gelebilecek tasarruflara da dikkat çekme amaçlanmaktadır.
\end{abstract}

Anahtar kelimeler: Medine, Sevr dağı, Buhârî, el-Câmiu’s-sahîh, hadis tenkidi, râvi tasarrufu.

\section{Giriş}

Hem Kur'ân-1 Kerim'in hem de hadislerin beyanına göre Mekke Allah Teâlâ tarafından harem bölgesi olarak tespit edilmiştir. ${ }^{1}$ Buna dayanarak

* Araştırma Görevlisi, Bursa Uludağ Üniversitesi İlahiyat Fakültesi. ORCID 000o-0002-8801-0726 tahirayas_61@hotmail.com

1 Nitekim Mekke'den bahisle, "Biz onları kendi katımızdan bir rızık olarak, her şeyin ürününün toplandiğl, güvenli ve kutlu bir yere yerleştirmedik mi?" (el-Kasas 28/57); "Çevrelerinde insanlar kapılı götürülürken (Mekke’yi) dokunulmaz ve güvenli bir yer yaptığımızı görmediler mi!" (el-Ankebût 29/67) buyrulmuştur. Mekke’nin fethi günü îrat ettiği hutbesinde Allah resulü de, "Allah’̀n yerleri ve göğü yarattığı gün Mekke’yi harem kıldığını ve kıyamete kadar da böyle kalacağını" ifade buyurmuşladır (Buhârî, "Sayd", 10; Müslim, "Hac", 44546). İslâm dininde harem bölgesi olarak tespit edilen yerler, buralara has hükümler, konu hakkında farklı görüşler, kaynaklar ve bazı yorumlar için bk. Öğüt, “Harem”, s. 127-32. 
şehrin belli bir bölümünde ${ }^{2}$ kan dökmek amacıyla silâh taşınması, avlanma dahil olmak üzere herhangi bir canlıya şiddet uygulanması, kesmek veya yolmak suretiyle bitkilerine zarar verilmesi haram kılınmıştır. İslâm’ın ikinci kutsal şehri konumundaki Medine’nin böyle bir hususiyeti bulunup bulunmadığ $\breve{l}_{1}$ konusunda ise âlimler ihtilâf etmişlerdir. ${ }^{3}$

Medine’nin haremliği, tespit edilebildiği kadarıla en erken (hicretin akabinde) Medine vesikasında söz konusu edilir. Vesikanın maddelerinden biri, "Medine vadisinin anlaşma tarafları için harem kılınmış" olduğudur. ${ }^{4}$ Bunun yanında Hz. Ali (ö. 40/661), Zeyd b. Sâbit (ö. 45/665 [?]), Sa'd b. Ebû Vakkās (ö. 55/675), Ebû Hüreyre (ö. 58/678), Enes b. Mâlik (ö. 93/711-12) gibi pek çok sahâbîden, açıç̧a Hz. Peygamber'in Medine’yi harem kıldığına, burada avlanmanın yasak olduğuna dair rivayetler nakledilmiştir. Medine’nin harem bölgesi olduğuna delâlet eden bu hadislerde sınır tespitinin farklı şekillerde yapıldığı görülür. Bu hadislerin bir kısmında herhangi bir sınıra işaret edilmeden sadece Hz. Peygamber'in, "Medine'yi harem kıldım"5 veya "Medine haremdir" ifadesi yer alır. Sınır tespitinin "taşlık" ve "dağ" gibi genel isimlerle yapıldığı rivayetler de vardır. ${ }^{8}$

2 Mekke hareminin sınırları için bk. Öğüt, "Harem”, s. 128.

3 Mâlikî, Şâfiî ve Hanbelîler Mekke gibi Medine’nin de özel hükümler gerektiren bir harem bölgesi olduğu görüşündedir (İbn Kudâme, el-Mugnî, III, 323-24). Hanefîler'e göre ise Medine'nin harem bölgesi yoktur (Tahâvî, Şerhu meâni'l-âsâr, IV, 196; Serahsî, el-Mebsût, IV, 187). Medine'nin harem bölgesi olduğunu ifade eden rivayetlerin bir kısmını mensuh addeden ya da tevil etmeye çalışan, bazısını da haber-i vâhid olduğu gerekçesiyle dikkate almayan Hanefîler bu konuda aksi yönde nakledilen/yorumlanabilecek rivayetleri esas almışlardır (bk. Yılmaz, İslâm Hukuku Açısından Mekke ve Medine Haremi, s. 217-23).

4 İbn Hişâm, es-Sîre, I, 504; Ebû Ubeyd, Kitâbü'l-Emvâl, s. 255; Hamîdullah, İslâm Anayasa Hukuku, s. 96-102.

5 Abdullah b. Zeyd b. Âsım'dan Resûlullah’n şöyle buyurduğu nakledilmektedir: "İbrâhim Mekke’yi harem kıldı ve ehli için dua etti. Ben de İbrâhim’in Mekke'yi harem kıldığı gibi Medine’yi harem kılıyorum..." (Müslim, Hac, 454; İbn Abbas'tan gelen benzer bir rivayet için bk. İbn Ebû Şeybe, el-Musannef, VII, 295).

6 Sehl b. Huneyf aracılığı ile nakledilmektedir: Resûlullah Medine’ye işaret etti ve "Burası harem ve güvenilir bir yerdir” buyurdu (İbn Ebû Şeybe, el-Musannef, VII, 295).

7 "Taşlık" olarak verdiğimiz bu ifade rivayetlerde "harre" (حرة) veya "lâbe" (لابة) olarak gelmektedir. Yâkūt el-Hamevînin naklettiğine göre bu taşlar sanki ateşte yanmış gibi siyahtır (bk. Mu'cemüll-büldân, II, 245). Muhammed Hamîdullah ise "Lâbe, lav kelimesinin eski Arapça’sıdır ve volkanik lavların yayılması ile oluşmuş ova anlamına gelir. Harre ise etrafa yayılmış lavların sıcaklığı ile yanmış taş veya toprakları belirtir" açıklamalarını yapmaktadır (Hamîdullah, Hz. Peygamber'in Savaşları, s. 3o). Harre ve lâbe için ayrıca sırasıyla bk. İbnü'l-Esîr, en-Nihâye, I, 357; II, 617-18.

8 Konuyla alâkalı Zeyd b. Sâbit aracılığı ile gelen rivayet şöyledir. Şürahbîl b. Sa'd anlatıyor. Zeyd ile çarşıdaydık. Oradakiler bir kuş yakalamışlardı, Zeyd’i görünce kuşu bana bırakıp kaçtılar. Zeyd kuşu aldı ve serbest bıraktı, ardından başıma vurarak, "Bilmiyor 
Büyük bir bölümünü $\mathrm{Hz}$. Ali’nin k1lıcının kınında muhafaza ettiği sahîfe rivayetinin teşkil ettiği hadislerde ise Medine'nin harem bölgesinin sınırları için Ayr ve Sevr dağlarına işaret edilir. Bu rivayetlerin bir kısmında sınırlardan biri net olarak belirtilmek yerine müphem lafızlarla ifade edilmiştir. Her iki sınırın müphem zikredildiği hadisler yanında sınılardan birini Uhud dağı olarak belirten rivayetler de bulunmaktadır.

Hz. Ali’nin elinde bulunan bu sahîfede, ${ }^{9} \mathrm{~Hz}$. Peygamber müslümanların zimmeti, zekât, diyet gibi bazı konulara değinmekte, Medine'nin harem oldugunu belirtmekte ve bunu ihlâl edenin lânete duçar olacağından bahsetmektedir. Rivayetin metni şöyledir:

Ali b. Ebû Tâlib, "Bizim yanımızda, Allah’n kitabından ve şu sahîfeden başka okunan yazılı bir şey yoktur" dedi. (Rivayeti nakleden Yezîd b. Şerîk dedi ki) Bundan sonra Ali, o sahîfeyi çıkardı. İçinde (diyet konusunda) yaralamalar ve develerin yaşları ile alâkalı birtakım hükümler vardı. Onda şunlar da vardı: Medine’nin Ayr dağı ile Sevr dağı arasında / Ayr dağından şuraya kadar olan sahası harem bölgedir. Kim Medine’nin bu haremi içinde (kitap ve sünnete aykırı) bir iş yapar yahut bir bidatçıyı barındırırsa Allah’̉n, meleklerin ve bütün insanların lâneti onun üzerine olsun. Ondan kiyamet günü hiçbir tövbe ve hiçbir fidye kabul olunmaz. Her kim kendi efendilerinin izni olmadan başka bir kavmi veli edinirse Allah’̉n, meleklerin ve bütün insanların lâneti onun üzerine olsun. Ondan kıyamet günü hiçbir tövbe ve hiçbir fidye kabul olunmaz. Müslümanların emanı birdir. Onların en aşağı olanları dahî bir harbîye eman verdiğinde, o eman bütün müslümanlarca muteber olur. Kim bir müslümanın verdiği

musun? Resûlullah Medine’nin iki taşlığı arasını harem kıldı" buyurdu (Taberânî, el-Mu'cemüll-kebîr, V, 150; ayrıca bk. İbn Ebû Şeybe, el-Musannef, VII, 295; yine kuş avlanma vakasını muhtevî, iki taşlıktan bahseden Abdurrahman b. Avf ve Ubâde b. Sâmit’ten gelen rivayetler için sirasiyla bk. Bezzâr, el-Müsned, III, 221; Taberânî, elMu'cemüll-kebîr, VI, 67. Sa'd b. Ebû Vakkās'tan gelen Medine’nin iki taşlığı arasında avlanmanın yasak olduğunu muhtevî bir diğer rivayet grubu için bk. İbn Ebû Şeybe, el-Musannef, VII, 295; Müslim, "Hac", 459, 460. Hz. İbrâhim’in Mekke’yi harem kılmasına atıfta bulunan ve Medine'nin de iki taşlık arasının harem kılındığını ifade eden, Câbir b. Abdullah ve Ebû Saîd el-Hudrîden gelen rivayetler için sırasıyla bk. Müslim, "Hac", 458; İbn Ebû Şeybe, el-Musannef, VII, 295. Enes b. Mâlik aracıllğ̆ ile nakledilen ve harem bölgeye "iki dağ arası" olarak işaret edilen rivayetler için bk. Buhârî, "Et 'ime", 28; Müslim, "Hac", 462; Ahmed b. Hanbel, el-Müsned, XX, 68).

9 Hz. Ali'nin bu sahîfesi, hadis kaynaklarındaki ilgili rivayetlerin bir araya getirilmesi suretiyle, Rif'at Fevzî Abdülmuttalib tarafından muhtevası tahlil edilerek Sahîfetü Alî b. Ebî Tâlib adıyla yayımlanmıştır (Kahire: Dârü’s-selâm, 1406/1986). Hadislerin Hz. Peygamber zamanında yazılması açısından önem arzeden (Sahîfe, s. 37-50) bu sahîfe bazı Şiî inançları ile ilişkilendirilebilecek unsurlar barındırması açısından da ayrıca önemlidir (bu konuda bk. Kuzudişli, Şîa ve Hadis, s. 127-32, 153-57). 
ahdi bozarsa Allah’ın, meleklerin ve bütün insanların lâneti onun üzerine olsun. Kıyamet günü ondan ne bir tövbe ne de bir fidye kabul olunur. ${ }^{10}$

Bu noktada, Medine'nin harem bölgesi için işaret edilen iki sınır üzerinden -özellikle Sevr dağı üzerinden- hadise eleştiriler yöneltilmiş, bu dağın/ dağların Medine'de değil de Mekke'de biliniyor olmasından hareketle erken dönemden itibaren hadisin bu şekliyle doğru olmadığ rüleceği üzere, hadisi rivayet eden râviler ve eserlerine alan musannifler, bu eleştirilerin tesirinde kaldıkları gerekçesiyle, hadisin metninde ilgili kısımda birtakım tasarruflarda bulunmak durumunda kalmışlar ya da böyle bir şeyi yapmakla itham olunmuşlardır. Buhârînin (ö. 256/870) râvileri ve hatta bizzat Buhârî bu tasarrufu kasten yapmakla tenkit edilmişlerdir. Mesele biraz daha incelendiğinde Buhârî nüshalarının, dolayısıyla müstensihlerinin de bu tenkitten etkilendiği anlaşılmaktadır.

Bu makale Medine’nin harem sınırlarını Ayr ve Sevr olarak belirten rivayetin râvilerine, hadise eserinde yer veren Buhârî̀ye ve Buhârî müstensihlerine yöneltilmiş tenkitleri tahlil edip, hadis hakkında ortaya atılmış eleştirilerin daha sonra hadisin metni üzerindeki yansımalarını tespit etmeyi hedeflemektedir.

Medine’nin haremliği ile ilgili rivayetler yukarıda da ifade edildiği gibi başta Enes b. Mâlik olmak üzere daha pek çok sahâbîden nakledilmiştir. Ancak ihtiyaç olmadıkça bu rivayetlere değinilmeyecek, araştırma, meseleye esas teşkil eden Hz. Ali’nin sahîfesi üzerinden takip edilecektir. Enes b. Mâlik’ten Amr b. Ebû Amr vasıtasıyla gelen rivayetlerin bağlamı ve bu rivayetlerin isnatları Hz. Ali'nin sahîfesinde yer alan rivayetten tamamen farklıdır. ${ }^{11}$ An-

10 İki sınırın Ayr ve Sevr şeklinde açık geldiği sahîfe rivayetleri için bk. Tayâlisî, Müsned, I, 152; Abdürrezzâk es-Sanânî, el-Musannef, IX, 263; İbn Ebû Şeybe, el-Musannef, VII, 295; Ahmed b. Hanbel, el-Müsned, II, 51-52, 304, 428; a.mlf., Kitâbü's-Sünne, II, 542; Buhârî, "Ferâiz", 21; Müslim, "Hac", 467-68; "Itk", 20; Tirmizî, "el-Velâ ve’l-hibe”, 3; Ebû Dâvûd, "Menâsik", 97; Nesâî, es-Sünenü'l-kübrâ, IV, 258; Ebû Avâne, Müsned, III, 239-40; Ebû Ya'lâ, el-Müsned, I, 228, 254; Tahâvî, Şerhu meâni'l-âsâr, IV, 191, 318; İbn Hibbân, Sahîh, IX, 32. İkinci sınırın "kezâ" şeklinde müphem geldiği rivayetler için bk. Buhârî, "Cizye", 10; 17, "Fezâilü'l-Medîne", 1, "İ'tisâm", 5. Hz. Ali'den nakledilen sahîfe rivayetinin hiçbir tarikinde her iki sınır birden müphem değildir. Harem bölgenin "iki taşlık arası" olarak ifade edildiği sahîfe rivayetleri için bk. Ahmed b. Hanbel, el-Müsned, II, 267; İbn Hibbân, Sahîh, IX, 30. Sınıra mutlak olarak işaret edilen sahîfe rivayetleri için bk. Ebû Avâne, Müsned, III, 239; Taberânî, el-Mu'cemü'l-evsat, V, 266; VI, 356.

11 Hayber dönüşü îrat edildiği anlaşılan bu hadislerin tamamında Hz. Peygamber, Uhud'u gördügünde, "Bu bizim kendisini sevdiğimiz kendisinin de bizi sevdiği bir dağdır” der ve ardından Medine'ye dönerek, "Hz. İbrâhim'in Mekke’yi harem kıldığı gibi ben de Medine’nin iki taşlı̆̆ı arasını harem kılıyorum” buyurur (ilgili rivayetlerin bir kısmını görmek için bk. Buhârî, “Cihâd”, 74, "Enbiyâ”, 11, "Megāzî", 27; Mâlik b. Enes, el-Muvatta', 
cak Âsım el-Ahvel (ö. 142/759) aracılığ ile gelen rivayetler sahîfe rivayetiyle benzeşir ve bu rivayetlerin bir kısmında her iki sınırdan da müphem olarak bahsedilir. ${ }^{12}$ Bazı tenkitlere hedef olmuş bu rivayet, birtakım özellikleri sebebiyle konu dışında bırakılmıştır. Öncelikle rivayetin, Yezîd b. Hârûn kanalı hariç, hiçbir tarikinde sınırlardan birisi dahi açık olarak kayıtlı değildir. İlgili rivayetin çeşitli tariklerine Ahmed b. Hanbel (ö. 241/855), Buhârî, Müslim (ö. 261/875), Tahâvî (ö. 321/933) gibi musannifler yer vermiş olup metin aç1sindan bazı farklılıklar olsa da rivayetler sinırlara dair herhangi bir farklılık içermez. Âsım'dan Yezîd b. Hârûn aracılı̆̆ı ile gelen rivayetlerde ise harem bölgesine mutlak olarak işaret edilir. ${ }^{13}$ Ayrıca rivayet bir soru-cevap formuna sahiptir ve kanaatimizce Enes b. Mâlik bu soruya cevaben, sınırları açıkça söylemek yerine, soru sorana işaret ederek göstermek istemiştir. ${ }^{14}$

Ebû Hüreyre'den konuyla ilgili nakledilen rivayetlerin bir bölümünün de muhtevasının sahîfe rivayeti ile benzeştiği görülmektedir. Ebû Hüreyre'den "A'meş $\rightarrow$ Ebû Sâlih" kanalıyla gelen bu rivayetlerin bir kısmında mutlak olarak "Medine haremdir" denilirken ${ }^{15}$ bir kısmında sınırlara "iki taşlık" olarak işaret edilir. ${ }^{16}$ Bazı rivayetlerde ise iki sınır Ayr ve Sevr olarak açıkça belirtilir. ${ }^{17}$

Râfi‘ b. Hadîc'den (ö. 73/692), "Hz. İbrâhim’in Mekke’yi harem kılması üzerine Hz. Peygamber'in de, 'iki taşlık arası' Medine’yi harem kıldığını”

II, 889; Saîd b. Mansûr, Sünen, II, 296; yine aynı tarikle gelen ancak sınırlara "iki dağ arası" şeklinde işaret eden rivayetler için bk. Buhârî, "Et'ime”, 28, "Daavât", 35; Müslim, "Hac", 462; Ahmed b. Hanbel, el-Müsned, XX, 68).

12 Sahîfe rivayetinin belli bir pasajını içeren bu rivayetlerde genellikle Âsım el-Ahvel, Enes b. Mâlik'e Hz. Peygamber'in Medine’yi harem kılıp kılmadığını sormakta, Enes de, "Evet şuradan şuraya harem kıldı" cevabını vermektedir (Buhârî̀, "İtisâm", 6; Müslim, "Hac", 463; soru sormaksızın nakilleri için bk. Buhârî, "Fezâilü’l-Medîne", 1; Ahmed b. Hanbel, el-Müsned, XXI, 149-50 [Enes b. Mâlik'in cevabi "Şuradan şuraya" şeklindedir]).

13 Enes b. Mâlik kendisine yöneltilen "Medine harem midir?" sorusuna, "Evet Medine haremdir" cevabını vermektedir (İbn Ebû Şeybe, el-Musannef, VII, 296; Ahmed b. Hanbel, el-Müsned, XX, 354; Müslim, “Hac", 464).

$14 \mathrm{Bu}$ rivayetlerin isnat şeması için bk. EK-I.

15 Müslim, "Hac", 469, 470.

16 Bezzâr, el-Müsned, XVI, 126. Bezzâr (ö. 292/905) söz konusu rivayetin ardından, "Biz bu hadisi Ebû Sâlih'in Ebû Hüreyre'den naklettiğini sadece A'meş'in rivayeti sayesinde biliyoruz" diyerek rivayetteki teferrüde dikkat çekmektedir.

17 Beyhakī, es-Sünenüll-kübrâ, V, 321. Ebû Hüreyre'den nakledilen diğer rivayetlerin bir kısmında, Hz. İbrâhim'in Mekke'yi harem kılmasına atfen Hz. Muhammed'in de Medine'yi iki taşlık arası harem kıldığı ifade edilmektedir (Bezzâr, el-Müsned, XV, 237). Diğer bir rivayette ise Ebû Hüreyre, "Medine ceylanlarının yayıldıklarını görsem, onları ürkütmem” demesinin ardından Resûlullah’ın Medine’yi iki taşlık arası harem kıldığını söylemektedir (Müslim, "Hac", 471; Bezzâr, el-Müsned, XIV, 162). 
ifade eden rivayetler nakledilir. ${ }^{18}$ Bunlara ilâveten bir rivayette Medine’nin "iki taşlık" arası harem bölge oluşunun, Râfi' b. Hadîc'de bulunan bir ceylan derisi üzerine yazılı olduğundan bahsedilir. ${ }^{19}$

Hz. Ali'den nakledilen sahîfe rivayetleri büyük çoğunlukla "A'meş $\rightarrow$ İbrâhim et-Teymî $\rightarrow$ Yezîd b. Şerîk” tarikiyle gelmektedir. Ebû Hassân, Mâlik el-Eşter ve Ebû Cühayfe'nin bu tarikten farklı olarak Hz. Aliden naklettikleri sahîfe rivayetlerinde sinırlara ya "iki harre" olarak işaret edilir ya da mutlak haremlikten bahsedilir. ${ }^{20}$ Ebû Hüreyre ve Râfi' b. Hadîc'den nakledilen rivayetlerle birlikte düşünüldügünde, Hz. Ali’nin sahîfesinde herhangi bir şekilde Medine’nin sınırlarından bahsedilmediği veya iki sınıra isim verilmeden işaret edildiği, Ayr ve Sevr şeklindeki tasrihin ise daha sonra râviler tarafından yapıldığ 1 söylenebilir. Nitekim sahîfe rivayetini A'meş'ten Zeyd b. Ebû Üneyse (ö. 125/743 [?]) kanalıyla alan Ebû Avâne’nin (ö. 316/929) eserinde ilgili kısmın “المدينة حرم"; İbn Hibbân’n (ö. 354/965) eserinde ise “ما بين لابتيها" şeklinde olduğu görülür. ${ }^{21}$ Ancak Medine’nin fizikî yapısı dikkate alındığında şehrin kuzey ve güneyden iki dağ; doğu ve batıdan ise iki siyah taşlık alan ile çevrili olduğu bildirilir. Bunun neticesinde Hz. Peygamber iki taşlı̆̆a işaret eden, lâbe veya harre rivayetlerinde Medine'nin doğu-batı yönündeki sınırlarından bahsetmekte, Ayr ve Sevr dağlarını söz konusu ettiğinde ise şehrin kuzey-güney yönlerinden sınırını dikkate almış olmaktadır. ${ }^{22}$ Dolayısıyla gerek Hz. Ali'den gerek Ebû Hüreyre'den nakledilen sahîfe rivayetlerindeki söz konusu farklılığa başka birtakım etkenlerin yol açtığı anlaşılmaktadır.

Hz. Ali'den nakledilen sahîfe rivayetinin bütün tarikleri bir araya toplandığında üç farklı metin grubu ortaya çıkar: 1. Medine’nin harem bölgesine (Ayr, Sevr, kezâ şekillerinde) iki sınıra işaret etmek suretiyle değinen rivayetler, 2. Medine'nin harem bölgesine (haremdir, iki taşlık arası haremdir gibi) herhangi bir şekilde değinen rivayetler ve 3 . Medine'nin harem kılınmasına hiç temas etmeyen rivayetler. Bu noktada ilk grup rivayetler esas malzemeyi teşkil ederken, yeri geldiğinde diğer rivayetler de ilgisi olduğu ölçüde konuya dahil edilecektir.

18 Bu rivayetler için bk. Müslim, “Hac”, 456; Taberânî, el-Mu'cemü'l-kebîr, IV, 257-58.

19 Müslim, "Hac", 457; Ahmed b. Hanbel, el-Müsned, XXVIII, 508.

20 Sirasiyla bk. Ahmed b. Hanbel, el-Müsned, II, 267; Taberânî, el-Mu'cemü'l-evsat, IV, 356; $\mathrm{V}, 266$.

21 Ebû Avâne, Müsned, III, 239-40; İbn Hibbân, Sahîh, IX, 30.

22 Nevevî, el-Minhâc, IX, 143; Rifâî, el-Ehâdîsül-vâride fî fezâili'l-Medîne, s. 40-41; Hamîdullah, İslâm Peygamberi, s. 171; Çelikkol, "Hicri Birinci Yüzyılda Medine Şehri”, s. 1-4; Bozkurt - Küçükaşc1, "Medine", s. 305. Medine şehrinin fizikî yapısı hakkında bk. Ali Hâfız, Fusûl, s. 15-17; Watt, "al-Madīna”, s. 994; Hamîdullah, Hz. Peygamber'in Savaşlarl, s. 55-75. 
Rivayete yöneltilen tenkitlere geçmeden önce kaynaklardan, özellikle coğrafî kaynaklardan hareketle rivayette geçen iki dağın Medine’de bulunup bulunmadığı veya Medine'de hangi dağların bulunduğu meselesine değinmek gerekmektedir.

\section{Medine’nin Coğrafî Yapısı}

Medine şehri kuzey ve güneyinden dağlar, doğu ve batısından siyah taşlık arazilerle (harre veya lâbe) çevrili geniş bir düzlük üzerinde yer alır. Dolay1sıyla Hz. Peygamber ve Medine halkı şehrin sınırlarına kimi zaman karşılıklı iki dağdan, kimi zaman da iki taşlık araziden hareket ederek işarette bulunmuştur. Rivayetler dikkate alındığında daha çok taşlık arazilerden hareket edildiği görülür. Esasen bu kullanıma Medine’nin harem kılındığına işaret eden rivayetler haricinde de sık başvurulur. Söz gelimi Hz. Peygamber'in, oruçlu olduğu halde eşi ile cinsel ilişkide bulunan bir sahâbîden kefâret için son olarak bir sepet hurmayı Medine'nin muhtaçlarına dağıtmasını istediğinde sahâbînin, "İki taşlık arasında benden fakiri mi var?" karşılığını verdiği nakledilir. ${ }^{23}$ Burada problem şehrin kuzeyinde ve güneyinde bulunan ve harem bölgeyi içine alan sınırları tayin eden dağların hangi dağlar olduğudur. Rivayetlerde Ayr, Sevr ve Uhud olarak ifade edilen bu dağların hangileri olduğu coğrafî kaynaklardan tespit edilmeye çalışılacaktır.

\section{Genel Coğrafî Kaynaklar}

Medine'de Sevr (ve Ayr) isminde bir dağın olup olmadığını tespit için coğrafî kaynaklara kronolojik olarak bakıldığında en erken Ya'kūbî (ö. 292/905'ten sonra) el-Büldân isimli eserinde, "Medine’nin biri Uhud diğeri Ayr olmak üzere iki dağı” olduğunu söyler, herhangi bir şekilde Sevr’i söz konusu etmez. ${ }^{24}$

Ebû Ubeyd el-Bekrî (ö. 487/1094), Ayr'ın "Medine taraflarında bir dağ" olduğu bilgisini nakleder. ${ }^{25}$ Sevr'in ise Mekke'de Hz. Peygamber' in (hicret esnasında) sığındığı bir dağ olduğunu söyler, ardından Hz. Peygamber'in Ayr ile Sevr arasını harem kıldığına dair hadisine atıf yaparak Ebû Ubeyd

23 Buhârî, "Savm", 30. Selmân-1 Fârîsîye, henüz müslüman olmadığı dönemde, Hz. Peygamber'in geleceğinin müjdelendiği bir rivayette, onun alâmetleri arasında "iki taşlık (harre) arasında bir yere hicret edeceği” haber verilir (Ebû Nuaym, Delâilü̈nnübüvve, I, 261). İmam Mâlik'in "Harreteyn sınırları dışında kalan hadis gücünü yitirir" ifadesi için bk. Ögüt, "Ehl-i Hadîs”, s. 510.

24 Ya'kūbî, el-Büldân, s. 151.

25 Ebû Ubeyd el-Bekrî, Mu'cem, III, 984. 
Kāsım b. Sellâm (ö. 224/838) ve Muśab ez-Zübeyrî (ö. 236/851) tarafından rivayete yöneltilen tenkitleri zikreder. ${ }^{26}$

Zemahşerî (ö. 538/1144), coğrafya ve tarih sözlügü niteliğindeki eserinde Ayr'in Medine'de, ${ }^{27}$ Sevr'in ise Mekke'de bir dağ olduğunu belirtir. ${ }^{28}$

Yâkūt el-Hamevî de (ö. 626/1229), Sevr'in Mekke'de Resûlullah'n hicret esnasında gizlendiği mağaranın bulunduğu dağ olduğunu söyler. ${ }^{29} \mathrm{Ebû}$ Ubeyd'in tenkidini aktaran Yâkūt "ilâ kezâ", "ilâ Uhud" şeklindeki rivayet farklılıklarına işaret ettikten sonra meşhur olanın ilk şekil olduğunu dile getirir. ${ }^{30}$ "Âir" maddesinde Medine'de bu isimde bir dağ bulunduğu ve bulunmadığı yönündeki zit ifadeleri nakleden ${ }^{31}$ Yâkūt, "Ayr" maddesinde Sevr'in Mekke'de Ayr'in Medine'de birer dağ olduğunu, Ayr-Sevr rivayetinin bir mânası olmadığını söyler. Çünkü Medine’deki Ayr dağı ile Mekke'deki Sevr dağı arasının harem olmadığını, rivayetteki Sevr hakkında bazı şeyler söylendiğini ve bazı hadis ehlince sahih olanın Ayr-Uhud olması gerektiğini ifade eder. ${ }^{32}$ Yâkūt el-Hamevî, aynı adla anılan farklı yerleri bir araya toplamayı amaçladığı, el-Müşterik vaz'an el-müfterik suk'an isimli eserinde Sevr adında beş farklı yerin olduğunu belirtir. İlkini Mekke'deki meşhur Sevr dağı olarak veren Yâkūt ikincisi için Ayr-Sevr hadisine işaret eder. Medine'de Ayr ve Sevr isminde dağların bulunmadığı yönünde bir tenkidi aktaran Yâkūt, Ayr'ın mevcudiyeti üzerinde durur ancak Sevr konusunda bir şey demez. ${ }^{33}$

Tarih-coğrafya ansiklopedisi niteliğindeki eseri ile tanınan Mağribli Ebû Abdullah el-Himyerî de (ö. 900/1395) Sevr için "Mekke'de Allah resulünün Hz. Ebû Bekir ile gizlendiği, Kur’ân-1 Kerim'de de zikri geçen mağaranın bulunduğu dağ" olduğu bilgisini verir. ${ }^{34}$

26 Ebû Ubeyd el- Bekrî, Mu'cem, I, 348.

27 Zemahșerî, el-Cibâl, s. 221.

28 Zemahşerî, el-Cibâl, s.72.

29 Yâkūt el-Hamevî, Mu'cemül-büldân, II, 86.

30 Yâkūt el-Hamevî, Mu'cemü'l-büldân, II, 87.

31 Yâkūt el-Hamevî, Mu'cemül-büldân, IV, 73.

32 Yâkūt el-Hamevî, Mu'cemü'l-büldân, IV, 172. Mu'cemü'l-büldân üzerine kaleme aldığ 1 ihtisar çalışması ile tanınan Hanbelî âlimi İbn Abdülhak el-Bağdâdî de (ö. 739/1338) Sevr'in Mekke'de Resûlullah’ın gizlendiği bir dağ olduğunu ifade eder, Ebû Ubeyd'in tenkidini aktarır ve rivayetin farklı şekillerde yorumlandığını belirtir (Merâsıdülıttılấ, I, 302); ayrıca Medine'de Ayr adında birbirine mukabil iki farklı dağın olduğunun söylendiğini nakleder (Merâsıdü'l-ıttılâ‘' II, 974).

33 Yâkūt el-Hamevî, el-Müssterik vaz'an, s. 91.

34 Himyerî, er-Ravzül-mi'târ, s. 151, 425. 
Genel coğrafya kaynaklarına bakıldığında Sevr'in, “Mekke’de Hz. Peygamber'in hicret esnasında Hz. Ebû Bekir'le birlikte sığındıkları mağaranın bulunduğu dağ” olduğu yönünde ortak bilgi verdikleri görülmektedir. Buna mukabil Medine'de Ayr adında bir dağın mevcudiyetinde herhangi bir problem görülmemektedir. ${ }^{35}$ Medine özelindeki coğrafî kaynaklarda ise mesele biraz farklılaşmaktadır.

\section{Medine Özelinde Kaleme Alınmıș Kaynaklar}

Medine’ye dair kaleme alınmış en erken çalışmalardan İbn Şebbe’nin (ö. 262/876) Târîhu'l-Medîneti'l-münevvere'sinde, Uhud dağ geniş sayılabilecek ölçüde ele alınır ${ }^{36}$ ve Mekke'deki Sevr dağından bahsedilir ${ }^{37}$ ancak Medine'deki Sevr dağı herhangi bir şekilde söz konusu edilmez. Eserde Medine’nin haremliğine işaret eden rivayetler yer almaz. "Uhud hakkında gelen rivayetler” bölümünde de aynı durum geçerlidir.

İbnü’n-Neccâr (ö. 643/1245), Medine’deki Sevr dağı hakkında bilgi veren en eski kaynaktır. O, tarihte Medine'de yaşanmış önemli olaylar, şehrin coğrafî yapısı, bu şehirde bulunmanın faziletleri, Mescid-i Nebevî başta olmak üzere şehrin diğer mescitleri gibi konuları genellikle hadisler 1şı̆̆ında incelediği ed-Dürretü's-semîne fî ahbâri'l-Medîne isimli eserinde ilgili hadisi ve Ebû Ubeyd'in söz konusu tenkidini nakleder ve ardından şu açıklamayı yapar: "Medine halkı Sevr dağını bilir. O Uhud'un arkasında küçük bir dağdır. Bunu inkâr etmezler." 38

Muhibbüddin et-Taberînin (ö. 694/1295) el-Ahkâm'inda, ${ }^{39}$ güvenilir olduğunu belirttiği -aslen Basralı olmakla birlikte hayatını Medine'de geçiren ve orada vefat eden- Ebû Muhammed Abdüsselâm b. Mezrû‘ el-Basrî̀den (ö. $699 / 1300)^{40}$ naklettiği bir kayıtta, Uhud'un hizasında, sol tarafından arkasına düşecek şekilde, küçük, Sevr denilen bir dağ bulunduğu belirtilir. İbn Mezrû‘ ayrıca bu toprakları bilen insanlardan pek çok kimseye bu soruyu yönelttiğinde aynı cevabı aldığını haber verir. Bunları aktaran Taberî, böylece rivayette Sevr'in zikrinin isabetli olduğunu anladıklarını ve buradaki problemin

35 İbn Hacer'in İbnü’s-Sîd el-Batalyevsînin (ö. 521/1127) el-Müselles ve Zübeyr b. Bekkâr’’n Ahbârül-Medîne isimli eserleri yanında başka atıflarla da Medine'de Ayr adında bir dağ olduğunu ispat etmeye çalışmasına dair bk. Fethu'l-bârî, IV, 98-99.

36 Bk. I, 79-86.

37 Bk. I, 8o-81.

38 İbnü’n-Neccâr, ed-Dürretüs-semîne, s. 52.

39 Müellif ve eseri hakkında bk. Hatiboğlu, "Muhibbüddin et-Taberî", s. 38-39.

4o Hakkında bk. Sehâvî, et-Tuhfetü'l-latîfe, II, 176. 
büyük ulemânın, şöhret bulmaması sebebiyle bu dağ hakkındaki bilgisizliklerinden, bu konuda gerekli araştırmayı yapmamalarından kaynaklandığını söyler. ${ }^{41}$

Kıraat ve hadis alanında döneminin önde gelen âlimlerinden Kutbüddin el-Halebî ise (ö. 735/1335), Sahîhu'l-Buhârî şerhinde ${ }^{42}$ yine aynı isimden ancak farklı olarak şu bilgileri verir: Abdüsselâm b. Mezrû́ el-Basrî Medine'de iken yanındaki bir rehber kendisine Medine’nin dağlarından vb. bahsetmektedir. Abdüsselâm b. Mezrû' Uhud'a vardıklarında, hemen onun yanında bulunan küçük bir dağı rehbere sorar ve adının Sevr olduğunu öğrenir. Halebî ardından "İște böylece rivayetin sahih olduğunu anladım" demektedir. ${ }^{43}$

İbn Mezrû‘ el-Basrînin talebesi Cemâleddin el-Matarî (ö. 741/1340) ${ }^{44}$ Medine'nin unutulmaya yüz tutmuş yönlerini tanıtmayı amaçladığı eserinde, rivayete yöneltilen tenkitleri zikrettikten sonra benzer ifadeler sarfeder, bu isimde bir dağın var olduğu bilgisinin rivayeti eleştirenlere ulaşmadığını, şayet böyle bir dağ bilinmese sonradan gelenlerin seleften bu bilgiyi nakletmeyeceklerini söyler. ${ }^{45}$

Medineli Ebû Bekir b. Hüseyin el-Merâgī (ö. 816/1414) ${ }^{46}$ Medine’ye dair kaleme aldığı bir muhtasar çalışmasında sonraki Medineliler'in se-

41 Rivayet küçük farklılıklarla şu kaynaklarda geçmektedir: Münâvî, Keşfü̉l-menâhic, II, 443; İ̉bn Hacer, Fethu'l-bârî, IV, 187; Aynî, Umdetül-kārî̀, X, 228.

42 Müellif ve eseri hakkında bk. Toksarı, "Kutbüddin el-Halebî”, s. 484.

43 İbn Hacer, Fethu'l-bârî, IV, 187; Aynî, Umdetüll-kārî, X 228-29.

44 Hakkında bk. İbn Hacer, ed-Dürerü'l-kâmine, V, 42-3; Sehâvî, et-Tuhfetüll-latîfe, II, 413-15. 45 Matarî, et-Ta'rîf, s. 182. el-Kāmûsü'l-muhît adlı sözlügü ile tanınan Fîrûzâbâdî (ö. 817/1415) söz konusu eserinde Mekke'deki meşhur Sevr dağına değinir, bununla birlikte Medine'de de bu isimde bir dağın olduğunu söyler. İlgili hadise işaret eden Fîrûzâbâdî, Ebû Ubeyd ve başka âlimlerin hadisteki Sevr'i Uhud’un tashife uğramış hali olarak görmelerine katılmaz, ardından Abdüsselâm b. Mezrû‘ el-Basrî̀den gelen Taberînin kaydettiği bilgileri Taberîye işaret etmeksizin aktarır. Devamında ise Afîfüddin elMatarînin (?), babasından (muhtemelen Cemâleddin el-Matarî) yazıp kendisine gönderdiği, "Uhud'un kuzeye bakan arka tarafında, yuvarlak, küçük, Sevr denilen bir dağ bulunduğunu Medine ahalisinin bildiği” ifadesine yer verir (s. 360). Fîrûzâbâdî, bir diğer eserinde, shhhati üzerinde ittifak olunmuş bu hadise, sadece Medine’de böyle bir dağ bilinmediği noktasından hareket ederek, bu kadar çabuk vehim bulunduğu iddiasının yöneltilmesine şaşırdığını belirtir. O ayrıca mekânların ve şehirlerin adlarının unutulma, değişikliğe uğrama, farklılık gösterme gibi sebeplerden dolayı, bu hususta kesin bilginin görme yoluyla (العيان المشاهد) elde edileceğini söylemektedir (el-Megānim, s. 82. Bu neşir eserin sadece coğrafî adlarla ilgili beşinci bölümüdür).

46 Kahire’de doğup ömrünün yaklaşık kırk yılını burada geçirmekle birlikte daha sonra Medine’ye yerleşmiş, elli yıl Medine'de yaşamış, bu şehrin kadılık, hatiplik ve imamlık görevlerini üstlenmiş ve bu şehirde vefat etmiştir (Ziriklî, el-A lâm, II, 63). 
leflerinden Uhud'un kuzey yönünden arka tarafında, Sevr denilen küçük bir dağ olduğunu naklettiklerini ve bunu bizzat müşahede ettiğini söylemektedir. ${ }^{47}$

Şehir tarihçiliği alanında, özellikle Medine hakkında uzmanlaşmış olan Nûreddin Ebü'l-Hasan es-Semhûdî (ö. 911/1506) Medine üzerine yazdığ Vefâül'-vefâ bi-ahbâri dâri'l-Mustafâ isimli eserinde bu konuyu ele almıştır. ${ }^{48}$ Rivayet farklılıkları ile birlikte ilgili hadisleri aktaran Semhûdî, iki dağ ile kastın "Ayr" ve "Sevr" olduğunu ifade eder. ${ }^{49}$ Ardından şu izahatta bulunur: "Ayr" Medine'de büyük, meşhur bir dağdır. "Sevr" ise Uhud'un arkasında küçük bir dağdır. Bu durum âlimlerden bir topluluğa gizli kalmış, onlar da hadisi müşkil addetmiş, "Sevr Medine'de değil Mekke’dedir" demişlerdir. ${ }^{50}$ Ayr'ın şöhretinde âlimler arasında problem olmadığını, garabetin Sevr'de olduğunu belirten Semhûdî, Ebû Ubeyd'in hadis hakkındaki ifadelerini de aktarır. Ebû Ubeyd'in ve başkalarının "Medine ehli böyle bir dağı bilmez" eleştirisine itiraz olarak Medine ve Mekke ehlinin bilmediği başka meşhur yerlerin de olduğuna dair nakiller yaparak karşllık verir ${ }^{51}$ ve bu hususu ancak ilim ehlinin bilebileceğini belirtir. Sevr'in Medine'de, Uhud'un arkasında bir dağ olduğuna dair -yukarıda da naklettiğimiz- pek çok âlimden alıntı yapar. ${ }^{52}$

47 İbn Hacer, Fethu'l-bârî, IV, 99. İbn Hacer, Ahbârü'l-Medîne muhtasarından bahsetmektedir. İbnün-Neccâr'nn ed-Dürretü̉s-semîne'sinden hareketle yapılmış bir çalışmadır (eser hakkında bk. http://www.taibanet.com/showthread.php?t=2039 [erişim tarihi: 15.10.2017]).

48 Semhûdî, Vefâüll-vefâ, I, 89-96.

49 Semhûdî, Vefâüll-vefâ, I, 90.

50 Semhûdî, Vefâül-vefâ, I, 92.

51 Yaptığı nakillerden biri şöyledir: "Rivayet Sevr lafzıyla sahihtir. Sadece bilinmemesinden hareketle râvilerin hata ettiğini söylemek gerekmez. Zira mekânların adları değişebilir, unutulabilir ve insanlar bunu bilmeyebilir. Mekke'de Muhassir vadisini ve daha başka yerleri sormuştum da kimse bana bunlar hakkında bir şey diyememişti" (Semhûdî, Vefâül-vefâ, I, 94). Semhûdî, “el-Beyân ve'l-intisâr sahibi” dediği tespit edemediğimiz bir müelliften bu nakilleri yapmaktadır (benzer ifadeler için bk. Zerkeşî, I'lâmü̈s-sâcid, s. 228-29).

52 Semhûdî, Vefâüll-vefâ, I, 94-96. Beyhakī, Ebû Ubeyd'in söz konusu tenkidini ihtisaren aktardıktan sonra şöyle demektedir: "Bana Ebû Ubeyd'den ulaştığına göre o, Kitâbü’lCebel'de şöyle der: Medine'de Sevr denilen küçük bir dağın olduğu bilgisi bana ulaştı"

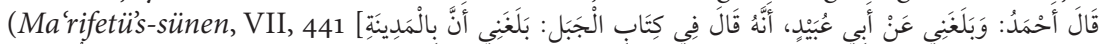

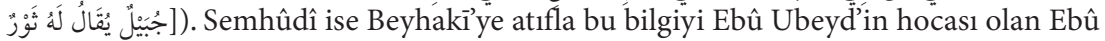
Ubeyde Ma'mer b. Müsennâya (ö. 209/824 [?]) nispet eder (Vefâül-vefâ, I, 94). Öncelikle isnadı açısından problemli olan ve sadece bu iki kaynakta tespit edebildiğimiz mezkûr nakilde adı geçen her iki âlime de Kitâbü̈l-Cebel adında bir kitabın izâfesi görebildiğimiz kadarıyla vâki değildir (Ebû Ubeyd'in Garîbü̉l-Musannef isimli eserinde, dağlara tahsis ettiği bölümde de konuyla ilgili bir bilgi bulunmamaktadır). Ayrıca Ebû Ubeyd'in tenkidinin tam zıddı yönde ifadeler içermesi rivayetin muhtevası bakımından da problemli olduğunu göstermektedir. Sehven iki kaynaktan birinde yanlış 
Görüldüğü üzere Medine özelinde kaleme alınmış günümüze ulaşan kaynaklarda Medine'de Sevr adında bir dağın mevcut olduğu bilgisi yer alır. İlâveten hadisin geçtiği muteber hadis koleksiyonları üzerine şerh çalışması yapan müellifler -özellikle Buhârî üzerine șerh yazan ve bu konuya değinmeden geçmeyen şârihler- Medineli âlimlerden veya günümüze ulaşmayan Medine'ye özel bazı kaynaklardan yaptıkları alıntılarla Ayr ve Sevr'in Medine'de olduğunu ortaya koymaya çalışmışlardır. ${ }^{53}$

\section{Son Dönem Çalışmaları}

Klasik kaynakların yanında son dönemde kaleme alınmış bazı eserlerde ve akademik çalışmalarda da bu konuya değinilmiştir. Eyüp Sabri Paşa (ö. 1308/1890) Arap yarımadasındaki yerleşim merkezlerinin, özellikle Mekke ve Medine’nin farklı pek çok yönünü ele aldığ 1 Mirâtü̉l-Haremeyn isimli çalışmasının Medine’ye ayırdığı bölümünde, "Uhud'un arkasında küçük, Sevr denilen bir dağcık olduğunu" söylemektedir. ${ }^{54}$

Kâmil Miras (ö. 1957) Tecrîd-i Sarîh'te, Enes b. Mâlik’ten gelen ve her iki sınırı müphem olarak belirten rivayetin şerhinde, ilk sınırın Âir olduğunu, ikincisinin Buhârînin bu babdaki bütün rivayetlerinde müphem geldiğini, fakat bunun Uhud olduğunun Abdullah b. Selâm'dan gelen rivayetle tasrih edildiğini söyler. Müslim’de ikinci sınırın Sevr olarak mervî olduğunu ancak bunun tenkit edildiğini belirten Miras, bu tenkide cevap mahiyetinde Fîrûzâbâdîden alıntılar yapar ve Medine’nin harem bölgesinin Âir dağı ile Uhud veya Sevr dağları arasında olduğunu belirtir. ${ }^{55}$

M. Fuâd Abdülbâkī (ö. 1968) Müslim'in el-Câmiu's-sahîh'inde ilgili rivayete düștügü ta'likte söz konusu hadisin Buhârînnin eserinde yer aldığını ve onun râvilerinin rivayetlerinde zayıflık ve şüpheden söz edilemeyeceğini belirtir. Musáab ez-Zübeyrî ve Ebû Ubeyd gibi âlimlerin hadisin metnini eleştirdiklerini, daha sonra gelen Ebû Ubeyd el-Bekrî, İbnü’l-Esîr ve Yâkūt

zabtedilmiş olan bu naklin Ma'mer b. Müsennâyya izâfesi daha doğru görünmekle birlikte sıhhati noktasındaki problemler daha çok öne çıkmaktadır. Bu kitabın Ma'mer b. Müsennâya ait Kitâbü'l-Hayl olduğu düşünülebilir. Ancak bu kitapta herhangi bir şekilde Ayr ve Sevr'den bahsedilmemektedir.

53 Nevevî (ö. 676/1277) konuya dair alıntıların ardından en son kendi düşüncesini "Medine’de Sevr adında bir dağın olması muhtemeldir, adı Uhud veya başka bir şey

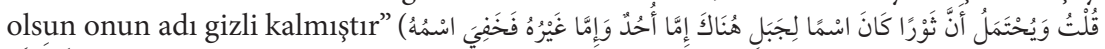

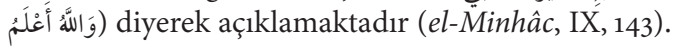

54 Eyüp Sabri Paşa, Mir'âtül-Haremeyn, II, 220.

55 Miras, Tecrîd-i Sarîh Tercemesi, VII, 228-9; ayrıca bk. a.mlf., "Âir", İslâm Türk Ansiklopedisi, I, 192. 
el-Hamevîyi hataya sevkettiklerini söyler ve Medine'de Sevr'in olduğuna dair uzunca nakiller yapar. ${ }^{56}$

TDV İslâm Ansiklopedisinde de "Medine'nin güneyinde yer alan ve Medine hareminin sınırlarından birini teşkil eden dağ” şeklindeki giriş bilgisiyle "Âir" maddesinde şu bilgiler verilmektedir:

Mekke gibi Medine'nin de bir haremi vardır ve bu saha Zülhuleyfe yakınlarındaki Âir (Ayr: عير) dağıyla Uhud dağı ve Küçük Sevr dağı arasında kalan bölgedir. Âir, Mescid-i Nebevînin yaklaşı 8 km. güneyinde, Sevr ise $8 \mathrm{~km}$. kuzeyindedir... Bazı müellifler Medine'de Âir ve Sevr adında dağlar bulunmadığını, bunların Mekke civarında yer aldığını iddia ederlerse de bu yanlıştır. Çünkü Mekke'de olduğu gibi Medine civarında da Sevr ve Âir adlı dağlar vardır. ${ }^{57}$

Hz. Ali'den gelen sahîfe rivayetlerini bir araya toplayarak neşreden Rif'at Fevzî Abdülmuttalib'e göre ise hadiste vehim olduğu iddiasını ele alan âlimler, Medine’nin kuzeyinde ve güneyinde bu isimde dağlar bulunduğunu tahkik etmişler ve böylece asıl vehmin "Medine'de Ayr ve Sevr adında dağlar bulunmadığı" iddiasında olduğunu ortaya koymuşlardır. ${ }^{58}$ Rif'at Fevzî konuya dair İbn Hacer, Semhûdî ve M. Fuâd Abdülbâkỉden alıntılar yapmaktadır.

Yine son dönemde yapılan bazı çalışmalarda da Medine'de Sevr adında bir dağın bulunduğu haritalar üzerinde ortaya konmaya çalışılmış, bugün Uhud'un arkasında kalan dağın isminin Sevr olduğu belirtilmiştir. ${ }^{59}$

Coğrafî kaynaklar ve şerhlerde verilen bilgilerden hareketle şunları söylemek mümkündür: Tenkitler kısmında görüleceği üzere Muśab ez-Zübeyrî ve açıkça belirtilmeyen bazı adlar haricinde rivayette Ayr'ın zikredilmesinde herhangi bir problem yoktur; coğrafî kaynakların verdiği bilgiler de rivayetin bu kısmını destekler. Genel kaynaklar ssrarla Mekke'de Hz. Peygamber'in hicret esnasında Hz. Ebû Bekir ile sığındığı Sevr dağından bahsetmekteyken, Medine özelinde kaleme alınmış kaynaklar ve bir kısım şerhler, Medine’de de Uhud dağının arka tarafında, Sevr adında küçük, meşhur olmamış bir dağın varlığından söz etmektedir.

56 Müslim, "Hac", 467 (II, 431-34, dn. 4).

57 Ağırakça, "Âir", s. 200-1.

58 Rif'at Fevzî, Sahîfe, s. 27.

59 Mekke'de ve Medine'de Sevr adında dağlar bulunduğuna dair bk. Şürrâb, el-Meâlimü'lesîre, s. 84; Medine haritası için ayrıca bk. s. 39. Sevr'in Mekke'de bir mağara, Medine'de Uhud'un arkasında bir dağ olduğuna dair fotoğraf ve haritalar için bk. Şevkī Ebû Halîl, Atlasül-hadîsin-nebevî, s. 109 (Ayr için bk. s. 280); ayrıca bk. Özben, Hadislerde Geçen Yer İsimleri, s. 82 (Ayr için bk. s. 76); Örenç, Hadislerde Kutsal Mekân Algısıı, s. 339-40. 
Erken dönem ve nispeten geç dönemde kaleme alınmış genel nitelikli coğrafî kaynaklarda Sevr'in Medine'de bulunduğu bilgisi yer almamasına mukabil daha geç tarihli Medine özelindeki kaynaklarda ve şerhlerde bu yönde mâlûmatın bulunması dikkat çekmektedir. Ayrıca Medine özelinde erken dönemde kaleme alınmış ve günümüze ulaşmış çalışmalardan İbn Şebbe'nin Târîh' inde de Medine'deki Sevr dağının herhangi bir şekilde söz konusu edilmemesi ilk bakışta bir problem arzetmektedir. ${ }^{60}$ Bu noktada pek çok kaynakta yer alan söz konusu hadisin muhtevasindan hareketle Medine'de bu adda bir dağın varlığına kanaat getirildiği söylenebilir. Ancak ilk dönemde yazılan coğrafya kaynaklarının konuları genel olarak ele aldığı, daha sonraki Medine'ye özel eserlerde konunun uzmanlarınca detaylı olarak işlendiği, İbn Şebbe'nin Târîh'inde de esasında Medine’nin haremliğinin hiç söz konusu edilmediği dikkate alındığında bu konudaki işkalin ortadan kalkacağı söylenebilir. Ayrıca verilen bilgilerde dağın bizzat müşahede edildiği vurgusu da dikkat çekmektedir. Genel nitelikli kaynakların tenkitlere atıfta bulunmakla yetinmeleri onların da Ebû Ubeyd ve diğer âlimlere tâbi olarak bu kanıya vardıklarını düşündürmektedir.

Anlaşılan o ki Medine'de Sevr adında bir dağ bazı Medineliler ile birlikte başta Ebû Ubeyd olmak üzere bir kısım âlime gizli kalmıştır. Bu noktada Sevr dağının -hicret gibi müslümanlar için çok mühim bir olay sırasında adının geçmesinin etkisiyle de- Mekke'de şöhret bulmuş olmasının, tenkitte bulunan Ebû Ubeyd ve diğer âlimleri yanıltmış olabileceği düşünülebilir. Aynı zamanda Uhud'un da yine etrafında cereyan eden bir savaş sebebiyle ayrıca şöhret bulmuş olması, zaten küçük olduğu belirtilen Sevr'i gölgelemiş olabilir.

Rivayete yöneltilen tenkitlerin bir kısmında Sevr yerine Uhud önerilmekte, rivayetin aslının Ayr-Uhud olduğu söylenmektedir. Medine’nin haremliği ile ilgili rivayetlerin bir kısmında Uhud'un söz konusu edilmesi, yani $\mathrm{Hz}$. Peygamber'in Uhud'a bakarak ona ve Uhud ehline övgüde bulunmasının

6o İbn Zebâle’ye (ö. 199/814'ten sonra) Ahbârül-Medîne adında bir eser izâfe edilir. Günümüze ulaşmamış olan bu eser yeniden inşa suretiyle neşredilmiştir (Medine 2003). Semhûdî, Vefâüll-vefầda ondan çokça alıntı yapar. Medine'deki Sevr dağı ile ilgili olarak İbn Zebâle'ye herhangi bir atıfta bulunmadığı gibi onun Medine'nin haremliği hususunda Ayr-Uhud rivayetine yer verdiğini belirtir (I, 93). İbn Zebâle, Medine'nin haremliğine işaret eden muhtelif rivayetler nakletmekle birlikte (bk. Ahbârül-Medîne, s. 188-91), atıflardan anlaşıldığı kadarıyla sahîfe rivayetine yer vermemiştir. Bu durum, söz konusu eserde de Medine’deki Sevr dağının söz konusu edilmediği ileri sürülerek, ilk anda bir problem olarak nitelendirilebilecekse de eserin tamamının günümüze ulaşmamış olması sebebiyle kesin bir netice elde etmek mümkün değildir. 
peşinden Medine’nin iki taşlığı arasını harem kıldığını belirtmesi, adı geçen âlimleri bu şekilde bir tenkide yöneltmiş olabilir. ${ }^{61}$

Medine'de küçük de olsa Sevr isminde bir dağ olduğu ifade edilmekle birlikte Buhârî hariç bütün hadis kaynaklarında Ayr-Sevr şeklinde geçen bu rivayete, Sevr üzerinden eleştiriler yöneltilmiştir. Bunun neticesinde hadis bazı zorlama yorumlara tâbi tutulmuştur. Fakat mesele bununla sınırla kalmamıştır. Birazdan aktaracağımız açıklamalarda da görüleceği üzere, eleştiriler başta Buhârî olmak üzere hadisçilerin bu hadise yaklaşımını etkilemiş, rivayetin Ayr-Sevr şekliyle hatalı olduğunu düşünenler hadis üzerinde birtakım tasarruflarda bulunmuş ya da bulunmakla itham edilmiştir.

Rivayet bağlamında ortaya atılan tenkitlerin "rivayete yöneltilen tenkitler" ve "rivayete yöneltilen tenkitlerin bir sonucu olarak hadisin râvilerine, Buhârî̀ye ve el-Câmi'u's-sahîh müstensihlerine yöneltilen tenkitler" olmak üzere iki grupta incelenmesi mümkündür. Burada önce rivayete yöneltilen eleştiriler, ardından bu eleştirilerin sebep olduğu tasarruflar ya da tasarruf iddiaları ele alınacaktır.

\section{Rivayete Yöneltilen Tenkitler}

Kaynaklarda rivayete yöneltilen tenkitler bağlamında tespit edebildiğimiz en erken eleştiri, meşhur dilci Ebû Ubeyd Kāsım b. Sellâm’a (ö. 224/838) aittir. Ebû Ubeyd, Garîbü'l-hadîs isimli eserinde, Resûlullah'in Medine’yi iki taşlık arası harem kıldığına dair söz konusu hadisinde geçen "lâbe" kelimesini açıkladıktan sonra, "Başka bir hadiste Resûlullah, Ayr ile Sevr arasını harem kılmıştır” der ve ardından şu açıklamalarda bulunur:

Bu hadis Iraklı râvilerin rivayet ettiği bir hadistir. Medineliler, Medine'de "Sevr" denilen bir dağ bilmez. Sevr Mekkededir. Anlaşılan o ki hadisin aslı "Ayr'dan Uhud'a kadar" şeklinde olmalıdır. Ben Medineliler'e Sevr'i sordum, onu bilemediler. Bu hadis Iraklılar'n rivayetidir. Medineliler Sevr'i bilmez. "Sevr, Mekke'dedir” demişlerdir. Ayr'ın ise Medine'de olduğu mâlûmdur, ben de onu gördüm. ${ }^{62}$

Ebû Ubeyd hadiste Sevr'in zikredilmesini problemli görür. Medine'nin yerlilerinin, şehirlerinde bu isimde bir dağı bilmediklerini bizzat kendilerine

61 Yine Hz. Peygamber'in Uhud ve Ayr dağlarını birlikte zikrettiği bir diğer rivayette,

"Uhud bizi sever biz de Uhud'u severiz ve o cennet kapılarından bir kapı üzerindedir. Ayr ise bize buğzeder biz de ona buğzederiz ve o cehennem kapılarından bir kapı üzerindedir" buyurduğu nakledilir (Taberânî, el-Mu'cemü'l-evsat, VI, 315).

62 Ebû Ubeyd, Garîbü'l-hadîs, I, 189 . 
sorarak teyit ettiğini belirten Ebû Ubeyd, rivayeti nakleden râvilerin Iraklı olduklarını söyler, ${ }^{63}$ dolayısıyla onların Medine’nin coğrafî yapısını Medine’nin sakinleri gibi bilemeyeceğini gerekçe göstererek hadisi tenkit eder. Daha sonra rivayete yöneltilen diğer tenkitlerin ve rivayet üzerinde vuku bulduğu iddia edilen bütün tasarrufların sebebi -Ebû Ubeyd haricinde ortaya atılmış eleştirilerin de etkili olma ihtimali ile birlikte- Ebû Ubeyd'in bu açıklamaları olabilir.

Erken tenkitlerden bir diğeri Ebû Ubeyd'in muasırı nesep âlimi Musáab ez-Zübeyrî (ö. 236/851) tarafından dile getirilmiştir. Kaynaklar Muśab’ın, "Medine'de Ayr ve Sevr diye bir dağ bulunmadığını" ileri sürdüğünü kaydeder. ${ }^{64}$ Yeğeni Zübeyr b. Bekkâr (ö. 256/870), Medine’de Âir adında bir dağın varlığından bahsederken, Muśab, "ne Ayr ne Âir ne de Sevr adında bir dağın Medine'de mevcut olduğu" görüşündedir. ${ }^{65}$ Burada, asıl meselenin "Sevr" ibaresi üzerinde dönmesine rağmen "Ayr"”n zikredilmesinin de problem olarak görülmesi dikkati çeker.

İbn Battâl (ö. 449/1057), Buhârî şerhinde Ebû Ubeyd ile birlikte Taberî̉en (ö. 310/923), bir grup Medineli’nin, Medine'de Sevr adında bir dağı bilmediklerini nakleder. ${ }^{66}$ Her ne kadar Taberînin konuya dair net ifadelerini tespit edemesek de o da erken dönemde rivayete tenkit yönelten isimler arasında değerlendirilebilir. Kādî İyâz (ö. 544/1149) Muśab ez-Zübeyrîye ilâveten başka âlimlerin de bu iki dağın Medine'de olduğunu inkâr ettiklerini bildirir. Ancak herhangi bir isim vermez. ${ }^{67}$

Rivayetin aslının "Ayr'dan Uhud'a" şeklinde olması gerektiğini söyleyen Ebû Ubeyd, bu görüşünde yalnız değildir. Hattâbî (ö. 388/998) Ebû Dâvud şerhinde konuyla ilgili olarak, "Bazı âlimler Ehl-i Medine’nin Medine’de Sevr diye bir dağ bilmediklerini, Sevr’in Mekke’de olduğunu ve hadisin aslının

63 Ebû Ubeyd bu hadisi isnatsız tahriç etmektedir. Sınırı Ayr ve Sevr olarak belirten rivayetlerin neredeyse tamamının isnadı "A'meş $\rightarrow$ İbrâhim et-Teymî $\rightarrow$ babası (Yezîd b. Şerîk et-Teymî) $\rightarrow$ Ali” şeklinde, tamamen Iraklı (Kûfe) isimlerden oluşur. Ebû Ubeyd, Iraklı Ebû Muâviye ed-Darîr (ö. 195/810) kanalıyla eserlerinde pek çok rivayete yer vermektedir. $\mathrm{O}$, aynı zamanda bu rivayeti A'meş'ten alan râviler arasında da yer almaktadır. Ebû Ubeyd'in A'meş'in hadislerine çoğunlukla Ebû Muâviye aracılığı ile ulaşması, burada rivayeti nispet ettiği Iraklı râvi grubunun da Ebû Muâviye vasıtası ile aynı isimler olabileceğini düşündürmektedir.

64 "Resûlullah’ın böyle buyurduğu nakledilmiştir ancak Medine'de Ayr ve Sevr diye bir dağ yoktur. Bu hadisin mânasını en iyi Allah bilir” ifadeleri için bk. Ebû Ubeyd elBekrî, Mu'cem, I, 348; ayrıca bk. Kādî İyâz, İkmâl, IV, 489; Nevevî, el-Minhâc, IX, 143.

65 İbn Kurkūl, Metâliu'l-envâr, V, 66.

66 İbn Battâl, Șerhu Sahîhi'l-Buhârî, IV, 537.

67 Kādî İyâz, İkmâl, IV, 489. 
'Ayr'dan Uhud'a' şeklinde olması gerektiğini ileri sürdüler" der. ${ }^{68}$ Mâlikî fakih ve hadisçi Mâzerî ise (ö. 536/1141) isim vermeden, bazı âlimlerin, Sevr'in râviden kaynaklanan bir hata olduğu ve doğrusunun Uhud olacağ 1 şeklinde görüş belirttiklerini söyler. ${ }^{69}$ Her iki âlim de muhtemelen Ebû Ubeyd'e işaret etmektedirler. Ebû Ubeyd'le hemfikir olan bir isim ise Hâzimîdir (ö. 584/1188). O, konuyla ilgili olarak "Ayr Medine'de bir dağdır. Bir hadiste Allah resulü Ayr ile Uhud arasını harem kılmıştır. Bu rivayet sahihtir. İfadenin 'ilâ Sevr' olduğu söylenmişse de, bunun bir anlamı yoktur" demektedir. ${ }^{70}$

Abdurrahman b. Abdullah es-Süheylî (ö. 581/1185) İbn Hişâm’n (ö. 218/833) es-Sîre’si üzerine kaleme aldığ ş̧erh çalı̧̧masında, "Medine, AyrSevr arası harem bölgedir" hadisinde vehim bulunduğunu, Çünkü Sevr'in Mekke'de bir dağ olduğunu söyler. Ona göre çoğunluğun nezdinde hadisin lafzı “" "ما بين عير الي كذا” șeklindedir. ${ }^{71}$

İbnü'l-Esîr (ö. 606/1210) Câmiu'l-usûl'de Medine topraklarında bu isimde bir dağ olmadığını fakat hadisin Ayr-Sevr şeklinde geldiğini söyler. Bazı âlimlerin "hadisin Ayr-Uhud șeklinde olması umulur, râvilerin tahrifine uğramıştır" dediklerini de nakleder. ${ }^{72}$ Aynı eserinde bir başka yerde hadisin Ayr-Uhud şeklinde olabileceğini dile getirir. ${ }^{73}$ en-Nihâye'de ise Mekke'deki Sevr dağına işaret ettikten sonra, az da olsa rivayetlerin bir kısmının AyrUhud şeklinde nakledildiğini, rivayetlerin çoğu Sevr olarak gelse ve böyle meşhur olsa da bunun râvi hatası olduğunu söyler. ${ }^{74}$

Ayr’ın Medine'de bir dağ olduğunu belirten Kastallânî (ö. 923/1517), Ebû Ubeyd tarafından rivayetteki Sevr ibaresine yöneltilmiş tenkidi aktarır. ${ }^{75}$ İkinci sınırın "kezâ" olarak geldiği rivayetler yanında Sevr ve Uhud şeklinde nakledilen rivayetlere dikkat çeker ve Uhud'un Medine'de Sevr'in ise Mekke'de olması hasebiyle Uhud rivayetinin tercih edildiğini belirtir. Bazılarının bunu râvinin hatası olarak açıkladığına, bazılarının da Ayr-Sevr rivayetine farklı yorumlar getirdiklerine işaret eder. ${ }^{76}$ Enes

68 Hattâbî, Meâlimu's-sünen, II, 223.

69 Mâzerî, el-Mu'lim, II, 117; Kādî İyâz, İkmâl, IV, 489.

70 Hâzimî, el-Emâkin, s. 703; aynı rivayet için bk. Nevevî, Tehzîbü’l-esmâ', III, 83. Nevevî, el-Minhâc'da Ebû Ubeyd ve Hâzimî ile ismini vermediği başka âlimlerin de Ayr-Uhud görüşünde olduklarını kaydeder (IX, 143).

71 Süheylî, er-Ravzüll-ünüf, IV, 134.

72 İbnü'l-Esîr, Câmiu'l-usûl, VIII, 26.

73 İbnü'l-Esîr, Câmiu'l-usûl, IX, 305.

74 İbnü'l-Esîr, en-Nihâye, I, 226.

75 Kastallânî, İrşâdüs's-sârî, III, 328-39.

76 Kastallânî, İş̧âdüss-sârî, V, 243. 
b. Mâlik’ten gelen, "Biz Uhud'u severiz..." rivayetindeki iki dağı, "Ayr ve Uhud” olarak açıklayan Kastallânî, Sevr rivayetinin, Sevr dağının Mekke'de bulunması sebebiyle müşkil kabul edildiğini söylese de "Medine'de de Sevr adında bir dağ olduğuna dair görüş, sika râviler vehimle suçlanamayacağ 1 için evlâdır" der. ${ }^{77}$

Buraya kadar zikrettiğimiz tenkitlerde şu hususlar öne çıkmaktadır: Bazı âlimler bu rivayette Sevr'in zikredilmesini problemli görüp hadisin aslının, sahih olan halinin "Ayr'dan Uhud'a" şeklinde olacağını ileri sürmüşlerdir. Bununla birlikte Ayr ifadesinde de problem olduğu gerekçesiyle rivayete tenkit yöneltilmiştir. Bu eleştirilerde hareket noktası Medine’de Sevr diye bir dağı özellikle Medine halkının bilmediğidir. Eleştiriler hadisi nakleden râvilerin bu Sevr kısmında vehimde bulundukları üzerinde yoğunlaşır.

Burada dikkat çeken husus bu âlimlerden bazılarının Sevr yerine Uhud ismini önermeleri, rivayetin bu şeklinin sahih olduğunu ileri sürmeleridir. Ancak Medine’nin haremliğine işaret eden rivayetler içerisinde sadece Abdullah b. Selâm'dan (ö. 43/663-4) gelen rivayette Uhud'a işaret edildiği, sahîfe rivayetinin ve diğer rivayetlerin hiçbir tarikinde Uhud'un söz konusu edilmediği görülmektedir. ${ }^{78}$

Görebildiğimiz kadarıyla Ahmed b. Hanbel'in el-Müsned’i ve Taberânînin el-Mu'cemül-kebîr'i ile muahhar bazı kaynaklarda, ${ }^{79}$ Abdullah b. Selâm'dan gelen bir haberde, ikinci sınır için "Uhud dağı" bilgisi mevcuttur. ${ }^{80}$ Buhârî de et-Târîhu'l-kebîr'inde Abdullah b. Selâm’nn biyografisinde söz konusu rivayete yer verir. ${ }^{81}$ Rivayet şöyledir:

Abdullah b. Selâm'dan nakledildiğine göre o şöyle demiştir: "Medine Ayr'dan Uhud'a kadar harem bölgedir. Resûlullah onu harem kılmıştır. Ben onun tek bir ağacını kesmem, kuşunu avlamam."

Rivayet Abdullah b. Selâm'dan "Muhammed b. Ebû Yahya el-Eslemî $\rightarrow$ Ubeydullah b. Huneys el-Gifârî” kanaliyla nakledilmekte ve Fudayl b.

77 Kastallânî, İrşâdü̉s-sârî, VIII, 231 والقول بأن بالمدينة أيضًا جبلًا اسمه ثور أولى لما فيه من عدم توهيم) الثقات (الثات

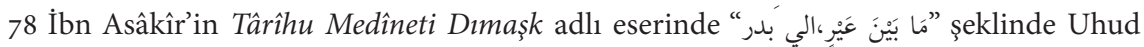
ve Sevr yerine Bedir'den bahsedilir (XLII, 396). İbn Asâkïr’in rivayeti aldı̆̆ ki râvilerden Ebû Ya 'lâ kendi eserinde bu rivayete "Ayr-Sevr" șeklinde yer vermiştir (el-Müsned, I, 228). Dolayısıyla burada bir tashiften bahsedilebilir ya da bir tahkik hatası düşünülebilir.

79 Meselâ bk. Ziyâeddin el-Makdisî, el-Ehâdîsül-muhtâre, IX, 458.

8o Ahmed b. Hanbel, el-Müsned, XXXIX, 197; Taberânî, el-Mu'cemü'l-kebîr, XIII, 170.

81 Buhârî, et-Târîhu'l-kebîr, V, 18-19. 
Süleyman'dan itibaren dağılım göstermektedir. Hadisin kendisinden üç farklı kola ayrıldığı Fudayl b. Süleyman (ö. 186/801), İbn Hibbân'ın es-Sikāt’’nda zikredilmesi $^{82}$ dışında münekkitler tarafından tenkit edilmiş bir râvidir. Onun hakkında Yahyâ b. Maîn (ö. 233/848) "leyse bi-sika”, Ebû Züráa erRâzî (ö. 264/878) "leyyinü'l-hadîs”, Ebû Hâtim er-Râzî (ö. 277/890) “yüktebü hadîsüh leyse bi'l-kavî” ve Nesâî (ö. 303/915) “leyse bi'l-kavî” değerlendirmelerinde bulunmuşlardır. Ayrıca İbn Hacer münkerü'l-hadîs olarak nitelendiğinden ve münker hadisleri bulunduğundan bahseder. ${ }^{83}$

Yine İbn Hibbân'ın es-Sikät'ında yer verdiği ${ }^{84}$ hadisin bir diğer râvisi Ubeydullah b. Huneys el-Gifârî, Medineli olması sebebiyle ayrıca bir önemi haiz olmakla birlikte, Dârekutnînin (ö. 385/995) "metrûk" olarak nitelemesi haricinde hakkında kaynaklarda herhangi bir değerlendirme bulunmamaktadır. ${ }^{85}$

Belâzürî (ö. 279/892-93) Fütûhu’l-büldân’inda "Ebû Mes'ûd el-Kattât $\rightarrow$ İbn Ebû Yahyâ el-Medenî $\rightarrow$ Ca'fer b. Muhammed $\rightarrow$ babası (Muhammed el-Bâkır; Muhammed b. Ali b. Hüseyin b. Ali b. Ebû Tâlib)" isnadıyla Resûlullah'ın Uhud veAyr arasını harem kıldığına dair bir rivayet nakleder. ${ }^{86}$ Ancak bu rivayetin isnadında kopukluk bulunmaktadır. Zira Muhammed el-Bâkır (ö. 114/733) Hz. Peygamber’e yetişememiş olup onunla arasında en az bir râvi daha bulunmalıdır.

Bunlardan hareketle ikinci sınırı Uhud olarak veren rivayetlere ihtiyatla yaklaşılması gerektiği anlaşılmaktadır. Rivayetin Ahmed b. Hanbel'in elMüsned'i istisna edilirse nispeten geç döneme ait Taberânînin el-Mu'cem'i ile birlikte hadis kaynağı vasfı taşımayan eserlerde yer alması da bu ihtiyatı destekler.

Ahmed b. Hanbel'in kaydettiği rivayette ikinci sınır Uhud şeklindedir. Ancak burada ilk sınırın müphem olarak bulunması (ما بين كذا و أحد) ayrıca dikkat çekmektedir.

82 İbn Hibbân, es-Sikāt, VII, 316.

83 İbn Hacer, Tehzîbü't-Tehzîb, VIII, 292.

84 İbn Hibbân, es-Sikāt, VII, 67.

85 İbn Hacer, Lisânül-Mîzân, V, 353 .

86 Belâzürî, Fütûhu'l-büldân, s. 18. 


\section{Tenkitlerin Rivayet Üzerindeki Yansımaları}

Rivayeti Sevr dağının Medine’de bulunmadığı gerekçesiyle tenkit eden âlimlerin bu eleștirilerinin hadisi rivayet eden râvileri, eserine alan musannifleri ve şerhini konu edinen şârihleri etkilediği, sonuçta rivayetin bazı zorlama yorumlara tâbi tutulduğu görülmektedir. Daha dikkat çekeni râvilerin veya musanniflerin hadisin metnine müdahalede bulunmak durumunda kalmaları veya bununla itham edilmeleridir. Çalışmanın bu bölümünde söz konusu eleştirilerin rivayet üzerindeki yansımaları tetkik edilmeye çalışılacaktır.

Rivayetin Ayr-Sevr şeklinin doğru olacağı ihtimalinden hareket eden bazı şârihler coğrafî kaynakların verdiği bilgilerden ve rivayete yöneltilen eleştirilerden sonra, farklı yorumlar getirme çabasına girmişlerdir. Buna göre rivayette geçen her iki dağ da esasında Mekke'de bulunmakta, Hz. Peygamber de bu noktada Mekke'de bu iki dağ arası kadar mesafenin Medine'de de harem bölgesi olduğunu söylemek istemiş olmaktadır. ${ }^{87}$ Ya da Mekke'de Ayr dağ 1 ile Sevr dağı arasını harem kıldığı gibi Medine’yi de harem kıldığını belirtmektedir. ${ }^{88}$ Bir diğer yorum da Hz. Peygamber' in Medine’nin etrafındaki iki dağı mecazen Ayr ve Sevr diye isimlendirdiğidir. ${ }^{89}$ Mekke'deki Sevr'den Medine'deki Ayr'a kadar harem olduğu şeklinde yorumlandığı da söylenmiştir. ${ }^{90}$

İlgili kısımdaki söz konusu farklılıkları, hadisin râvilerinin vehmi, hatırlayamaması gibi sebeplerle açıklayan âlimler bulunmakla birlikte daha ilginç olan, bunun hadisin râvilerince veya ilgili rivayetleri eserine alan müelliflerce kasten yapıldığının ifade edilmesidir. ${ }^{91}$ Öyle ki bununla itham edilen Buhârînnin râvileridir ve hatta bizzat Buhârînnin kendisidir. ${ }^{92}$ Bu eleştirile-

87 İbn Kudâme, el-Mugnî, III, 324; Yâkūt el-Hamevî, Mu'cemü’l-büldân, II, 87; Semhûdî, Vefâül-vefâ, I, 93.

88 Yâkūt el-Hamevî, Mưcemül-büldân, II, 87.

89 İbn Kudâme, el-Mugnî, III, 324; Semhûdî, Vefâül-vefâ, I, 93.

90 Yâkūt el-Hamevî, Mu'cemü'l-büldân, II, 87; Semhûdî, Vefâül-vefâ, I, 93.

91 Hadis metinlerinde tebdil, takdim, tehir, tashif, tahrif türünden râviler tarafından meydana gelen değişikliklere fazlaca örnek bulmak mümkündür. Burada söz konusu olan ise kasitlı bir müdahaledir (daha geniş bilgi için bk. Şeref Mahmûd el-Kudât, Esbâbü teaddüdìr-rivâyât fill-hadîsinn-nebeviyyişs-şerîf, Amman: Dârü’l-furkān, 1985; Süleyman Doğanay, Hadis Rivayetinde Râvi Tasarrufları ve Doğurduğu Problemler, İstanbul: İSAM Yayınları, 2009).

92 Buhârîye yöneltilmiş benzer bir tenkit için bk. Erul, "Tasarrufâtü’r-ruvât", s. 204. Ancak burada, söz konusu rivayette ayakların meshi yanında yüz ve dirseklerin de meshedilmesinden bahsedilmesine rağmen bu detay üzerinde durulmaması (söz gelimi Tahâvî, buradaki meshin "yıkamak" olduğu kanaatindedir. Şerhu meânil-âsâr, I, 34); İbn Ebû Şeybe'nin el-Musannef inde kısa olarak nakledilen rivayetin aynı isnatla Ahmed b. Hanbel'in el-Müsned'inde uzadığı iddia edilirken İbn Ebû Şeybe'deki uzun 
ri "hadisin râvilerine", "Buhârî̀ye" ve "Buhârîden el-Câmiu's-sahîh'ini alan râvilere, kitabını kopya eden müstensihlere dolayısıyla nüshalara” yönelik eleştiriler olmak üzere üç grupta incelemek mümkündür.

Bazı âlimler konuya, hadisin metnine kasttlı bir müdahaleden ziyade râvilerin zabt kusuru açısından yaklaşmışlardır. Buna göre rivayette, tenkitler neticesinde bir tebdil değil râvilerin unutması, ezberleyememesi, hatırlayamaması ve dolayısıyla bu ikinci sınırı "kezâ" olarak ifade etmeleri şeklinde bir zabt kusuru söz konusudur. Söz gelimi "Medine şehri Ayr-Sevr arası harem bölgedir" hadisinde vehim bulunduğu kanaatinde olan Süheylî, çoğunluğun hadisi "ما بين عير الى كذا" lafzıyla rivayet ettiğini, râvinin hadiste geçen

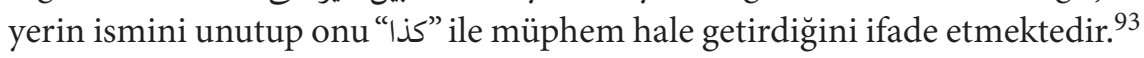
Süheylîye göre çoğu râvinin, hadisi müphem olarak rivayet etmesinin sebebi râvilerin unutmasıdır. Ancak görüleceği üzere onun meseleyi râvilerin unutkanlığı ile açıklaması isabetli değildir. Ayrıca Süheylînin ilk iddiasının aksine rivayetlerin büyük kısmı Sevr şeklinde açık olarak kayıtlıdır.

Hadis hakkında ortaya atılan tenkitlerin büyük bir kısmında ise "metne kasıtlı müdahale edildiği” iddiası söz konusudur. Buna göre ilk olarak hadisi rivayet eden râvilerin, eleştirilerin etkisinde kalıp, kasıtlı olarak hadisin metnine müdahil oldukları, hatalı olduğunu düşündükleri Sevr'i ya "kezâ" şeklinde müphem hale getirdikleri ya Sevr'in üzerine çizgi çektikleri ya da yerini boş bıraktıkları ifade edilir. ${ }^{94}$ İlâve olarak ikinci sınırın "Uhud" olarak kaydedildiği ancak birinci sınırın yani Ayr’in müphem zikredildiği, Ahmed b. Hanbel rivayeti için, Ayr'a yöneltilen tenkitlerin bir neticesi olarak benzer bir tasarruftan bahsedilebilir. Kādî İyâz İkmâlü̉l-Mu'lim’de şöyle der:

rivayetin $(I, 16)$ gözden kaçırılması ve rivayetlerin isnat şeması çizilerek tasarrufun hangi râviden kaynaklanabileceği tetkik edilmeden müdahalenin Buhârîye mâl edilmesi (İbn Hacer ve Aynî tasarrufun, Buhârînnin hadisi aldığı Âdem b. Ebû İyâs'tan kaynaklandığı kanaatindedirler. Fethu'l-bârî, X, 82; Umdetüll-kārî, XXI, 193) problem olarak gözükmektedir.

93 Süheylî, er-Ravzüll-ünüf, IV, 134.

94 Bu yönde ifadeler için bk. Yâkūt el-Hamevî, Mu'cemü'l-büldân, II, 87; Semhûdî, Vefâülvefầ, I, 92-3. Dil ve gramer yönünden hatalı nakledildiği düşünülen rivayetler karşısında takınılacak tavrın nasıl olacağı hususu ihtilâflıdır. İşitildiği gibi nakledileceğini söyleyenler yanında (Hatîb, el-Kifâye, I, 416-20) düzeltilerek rivayet edilmesi gerektiğini savunanlar da vardır (Hatîb, el-Kifâye, I, 428-33). Hatîb el-Bağdâdî, lahnın ıslahının câiz olduğu hususunda icmâ olduğunu belirtir (ayrıca bk. İbn Abdülber, Câmi', s. 108-12; Kādî İyâz, el-İlmấ', s. 183-6; Polat, Metin Tenkidi, s. 95-99). Bunların yanında bu tür hadislerin rivayet edilmemesi ya da mânanın dikkate alınması, mânaya tesir ediyorsa o takdirde düzeltme yapılması gerektiği şeklinde farklı görüşler de ileri sürülmüştür (konuya dair görüşler için bk. İfrenî, Fethu’l-mugīs, s. 26-31; Şehrî, Lahnürrruvât, s. 23-37). 
"Ayr" ve "Sevr" adları bir başka hadiste "kezâ kezâ" olarak gelmiştir. a) Ya râvileri bu iki ismi zabt edemedi. b) Ya da Muśab ez-Zübeyrî ve başka âlimlerin bu iki kelimeyi inkârlarından dolayı onları "kezâ" şeklinde ifade ettiler..."95

Kādî İyâz bu ilk ifadeleriyle bağlamı ve isnadı farklı olan Enes b. Mâlik rivayetlerini de meselenin içine katmış olmaktadır. ${ }^{96}$ Ancak anlaşıldığı kadarıyla Enes b. Mâlik'ten gelen rivayetler söz konusu problemin kapsamına girmemektedir. Bu rivayetlerin bizzat Enes b. Mâlik’ten, kendisine yöneltilen soruya cevaben, müphem olarak nakledildiğini düşünmekteyiz.

Her ne kadar sahîfe rivayeti için dile getirilmese de Kādî İyâz rivayette meydana gelen değişikliğin iki sebebi olabileceğini söyler: Birincisi, Süheylî̉nin de işaret ettiği gibi, hadisin râvilerinin her iki sınırı hıfz edememesidir. Diğeri ise hadisin râvilerinin ilgili kısımda tenkitlerin etkisinde kalarak tasarrufta bulunmalarıdır. Böylece râvilere yönelik ilk kasıtlı müdahale eleştirisi Kādî İyâz’dan gelmiş olmaktadır.

Her iki ismin müphem olarak zikredildiği rivayetler hakkında, râvilerin zabt açısından kusurlu olabilme durumlarına ilâveten, bazı âlimler tarafından ileri sürülen, "hem Ayr'ın hem de Sevr'in Medine'de olmadığı” yönündeki ifadelerin etkili olduğunu belirten Kādî İyâz, Buhârînin el-Câmiu'ssahîh'indeki sadece Sevr'in açık olarak kaydedildiği, ikinci ismin müphem geldiği sahîfe rivayetleri için ise şunları söyler:

Buhârînin kitabındaki râvilerin çoğu "Ayr"1 zikretmiş, "Sevr"e gelince, onun bu hadiste zikredilmesinin hatalı olduğunu düşündükleri için, onlardan kimi bunu ya "kezâ" şeklinde rivayet etmiş ya da yerini boş bırakmiştır.97

Kādî İyâz’ın müphem bırakmaktan ziyade Buhârî râvilerinin rivayetteki ikinci adın yerini boş bıraktıkları şeklindeki açıklaması dikkat çekicidir. Halbuki el-Câmiu's-sahîh'te böyle bir durum söz konusu değildir.

Bunun yanında bizzat Buhârî̀nin kendisinin de eleştirilerin etkisinde kalarak hadiste ikinci sınırın yerini boş bıraktığı ifade edilmiştir. İbnü’lMüneyyir (ö. 683/1284) Buhârînin bab başlıkları üzerine kaleme aldığı çalışmasında şöyle der:

95 Kādî İyâz, İkmâl, IV, 489; ayrıca bk. Kādî İyâz, Meşâriku’l-envâr, I, 136.

96 Sehârenpûrî de (ö. 1927) bu rivayetleri bahse dahil etmektedir (Bezlü'l-mechûd, IX, 386).

97 Kādî İyâz, İkmâl, IV, 489. 
el-Câmiu's-sahîh'in temel nüshalarında (ümmehât) "min Ayr ilâ...” olarak, sonu boş bırakılmış bir şekilde, vâki olan bu ifade, bir başka tarikten "min Ayr ilâ Sevr" şeklinde gelmiştir. Görünen o ki Buhârî, Medine ehlinin Medine'de Sevr adında bir dağ bulunduğunu inkâr etmesinden hareket ederek, bunu (yani Sevr kelimesi) kasten düşürmüştür... Buhârînin nezdinde onun vehim olduğu düşüncesi ortaya çıkınca onu sskat etmiş, hadisin geri kalanını zikretmiştir... ${ }^{98}$

İbnü’l-Müneyyir'in eleştirisinin dikkat çeken yönü, doğrudan Buhârîye yönelik olması ve bunu kasıtlı olarak yaptığını düşünmesidir. Buna göre Buhârî, rivayete yöneltilen eleştirilerin etkisinde kalmış ancak senedini güvenilir bulduğu bu hadisi eserine almaktan da geri durmamıștır. Bunu yaparken de hadiste şüpheli gördüğü yeri boş bırakmıştır. Kādî İyâz boş bırakma eylemini Buhârînin hadisi aldığ 1 râvilere izâfe ederken İbnü'l-Müneyyir Buhârî̀ye atfetmektedir.

Bir yeri boş bırakma ve daha sonra tekrar dönüp o yeri doldurma tavr1 Buhârînin eserini yazarken başvurduğu yollardan biridir. Diğer taraftan Buhârînnin eserini tamamlayamadığ 1 , müsvedde halinde biraktığ ${ }_{1}{ }^{99}$ daha sonra tekrar dönüp doldurmak üzere boşluklar bıraktığı ancak bunlara fırsat bulamadığg da ileri sürülmüştür. ${ }^{100} \mathrm{Bu}$ açıdan Buhârînin tenkide uğramış olan bu rivayeti eserine aldığı ancak bunu yaparken şüpheli olan ikinci sınırın yerini boş bıraktığg düşünülebilir. Ancak burada karşımıza ikinci sınırın "كذا" şeklinde mervî olduğu rivayetler yanında, el-Câmiu's-sahîh'te açıkça "Sevr" olarak kayıtlı tek rivayet çıkacaktır. Buhârî̀de söz konusu rivayet beş yerde nakledilmektedir. "Yûnînî nüshası esas alınarak neşredilmiş Buhârî baskılarında" sadece "Ferâiz" bölümündeki rivayette ikinci sınır "Sevr" olarak kayıtlıdır. Diğer rivayetlerde ise "kezâ" şeklinde müphemdir.

Bir rivayette geçen biraz müstehcen bir kelimenin yerinin Buhârî tarafından boş birakıldığı ve daha sonra müstensihler tarafından doldurulduğu belirtilmiştir. ${ }^{101}$ Buradan hareketle Buhârînin ilgili kısımdaki boş bırakma ey-

98 İbnül-Müneyyir, el-Mütevârî, s. 153.

99 Buhârî şârihlerinden Mühelleb b. Ebû Sufre (ö. 435/1044) onun son düzeltmeleri (tehzîb) yapamadığını söyler (el-Muhtasarün-nasîh, I, 150); (Buhârînnin, eserini müsvedde olarak bıraktığı yönündeki bir başka ifade için bk. Kastallânî, İrşâdü̉s-sârî, I, 23-24; Sezgin, Buhârînin Kaynakları, s. 170-71). Kastallânî burada tam aksi görüştedir ve eserde görülen düzensizliklerin daha sonraki rivayetlerden kaynaklandığını söylemektedir.

100 Bilen, İbn Hacer'in Buhârî Savunusu, s. 69.

101 İbn Hacer, Fethu'l-bârî, VIII, 189-90; Kastallânî, İrşâdü’s-sârî, VII, 34; Sezgin, Buhârî̀nin Kaynakları, s. 191. 
leminin müstensihlere, daha sonraki râvilere metne müdahale etme imkânı verdiği, dolayısıyla Sevr olarak kayıtlı tek rivayetin de bundan kaynakladığı düşünülebilir. Bu konuyu biraz ileriye bırakarak müstensihlere varmadan, hadisi rivayet eden râvilerin (ve eserine alan musanniflerin) rivayet üzerinde bir tasarrufunun olup olmadığını tespit etmek için söz konusu hadisin bütün tariklerinin bir araya getirilerek incelenmesi gerekmektedir.

İbn Hacer, şerhinde daha önce herhangi bir âlime nispet etmeden naklettiği, 102 "Buhârî, vehim olduğunu düşündüğü için bilerek Sevr'i müphem bırakmıştır” ifadelerini, bu sefer, şerhinde de istifade ettiği Buhârî şârihi İbnü’t-Tîn es-Sefâkusîye (ö. 611/1214) ${ }^{103}$ atfen verir:

"Buhârî, hata olduğunu düşündüğü için bunu (ipham etmeyi) kasten yapmıştır” sözüne gelince, bu olsa olsa İbnü’t-Tîn’in hatasıdır. Bu ifadeyi Buhârînin râvilerinin bir kısmı müphem olarak nakletmiştir. Buhârî ise "Cizye" bölümünde bu hadise yer vermiş ve Sevr’i de açıkça zikretmiştir. ${ }^{104}$

İbnü’t-Tîn Buhârînin kasıtlı bir müdahalesinden bahsederken, İbn Hacer ise burada eleştirilmesi gerekenin Buhârî değil, hadisin senedindeki râviler olduğunu söyler, ancak herhangi bir râviye işaret etmez. Ona göre Buhârî, hadisi işittiği gibi nakletmiştir.

Kādî İyâz ve İbn Hacer gibi isimler tarafından hadisin râvilerine yöneltilen ikinci sinırı zabt edememe ve tenkitlerden etkilenerek bu ikinci sinır üzerinde tasarrufta bulunma şeklindeki değerlendirmelerin hadisin isnat şeması üzerinden tetkiki yapılmalıdır. Burada nüsha farklarına geçmeden önce $\mathrm{Hz}$. Ali'den gelen sahîfe rivayetinin -Medine’nin haremliğine temas eden tariklerinin- isnat şeması verilerek metindeki olası tasarrufların izleri sürülmeye, bahis mevzuu tenkide dayanak teşkil eden farklllıkların hadisin râvilerinden kaynaklanıp kaynaklanmadığı veya hangi râviden kaynaklandığı tespit edilmeye çalışlacaktır (isnat şeması için bk. EK-2). ${ }^{105}$

102 İbn Hacer, Fethu'l-bârî, IV, 98.

103 Hakkında bk. Muhammed Mahlûf, Şeceretü’n-nûr, I, 242.

104 İbn Hacer, Fethu'l-bârî, IV, 99.

105 Tablo hazırlanırken Yûnînî nüshasına göre neşredilmiş Sahîh-i Buhârî baskıları esas alınmıştır. 
EK-2'deki şemada görüldüğüü üzere söz konusu rivayet Hz. Ali'den beş râvi vasitasıyla nakledilmektedir. Hâris b. Süveyd, ${ }^{106}$ Ebû Hassân, Mâlik el-Eşter ${ }^{107}$ ve Ebû Cuhayfe ${ }^{108}$ tariklerinde herhangi bir dağılım göstermemektedir. Rivayet "İbrâhim et-Teymî $\rightarrow$ Yezîd b. Şerîk" aracilığı ile A'meş’e gelmekte, A'meş’ten itibaren talebeleri vasıtasıyla farklı pek çok tarike ayrılmaktadır.

İkinci sınırın müphem bırakıldığı rivayetler sadece Buhârî tarafından nakledilmiştir. Hadis diğer bütün kaynaklarda Ayr-Sevr şeklinde açık olarak nakledilir. Ayr'ın Âir olarak yazımı ve Sevr'in bazı rivayetlerde Ayr'dan önce zikredilmesi haricinde "iki harre arası", "iki lâbe arası" ve "Medine haremdir" şeklindeki üç rivayet ayrıca dikkat çekmektedir.

Ebû Avâne ve İbn Hibbân’n "Ubeydullah b. Amr $\rightarrow$ Zeyd b. Ebû Üneyse" kanalıyla A'meş’ten naklettikleri, mutlak olarak ve iki taşlık şeklinde Medine’nin harem kılındığından bahseden rivayetler; Hz. Aliden Ebû Hassân aracılığı ile gelen "iki harre arası" şeklindeki rivayet ve Mâlik el-Eşter ile Ebû Cühayfe'nin naklettiği mutlak haremlikten bahseden rivayetler diğer bütün rivayetlere muhalif kalmaktadır. Bu durum manen rivayet, zabt kusuru, rivayetlerin tedahülü gibi sebeplerle açıklanabilir.

Buhârî, eserinde sahîfe rivayetini, Medine’nin harem kılındığına temas eden kısmıyla birlikte, beş yerde zikreder. ${ }^{109}$ Bunların dördünde ikinci sınır müphemdir. İkinci sınırın açık olarak kaydedildiği tek rivayetin tetkikini biraz ileriye bırakarak şema üzerinden bazı değerlendirmelerde bulunmaya çalışalım.

Öncelikle rivayeti nakleden râvilerin hemen hepsi -Kāsım b. Sellâm’ın da işaret ettiği gibi- Irak bölgesindendir. Burada A'meş'ten rivayeti alan Süfyân, Vekî‘ ve Hafs isimleri öne çlkar. Zira bu isimlerden gelen rivayeti eserine alanlar arasında rivayetin her iki şeklini de kitaplarına kaydetmiş musanniflerin varlığı dikkat çeker. Bu da ilk anda meydana gelen farklılığın bu isimlerin talebelerinden kaynaklandığını düşündürmektedir.

106 Dârekutnî, Şu'be’nin "A'meş $\rightarrow$ İbrâhim et-Teymî" aracilığı ile Hâris b. Süveyd'den yaptığı rivayetlerde, A'meş'in diğer talebelerine muhalif kaldığını, mahfuz olanın Süfyân es-Sevrî ve ona tâbi olarak nakilde bulunanların rivayetleri olduğunu söyler (el-İlelü'l-vâride, IV, 154).

107 Taberânî rivayetin ardından isnadda teferrüt bulunduğunu söyler (el-Mu'cemü’levsat, V, 266).

108 Taberânî burada da bir teferrüde işaret etmektedir (el-Mu'cemü'l-evsat, IV, 356).

109 Sahîfe rivayeti Buhârîde mezkûr tarik haricinde, "Mutarrif $\rightarrow$ Şa'bî $\rightarrow$ Ebû Cühayfe $\rightarrow$ Ali" kanalıyla da nakledilir (bk. "İlim", 39, "Diyât", 24, 31, "Cizye”, 171). Ancak bunların hiçbirisinde Medine’nin haremliği kısmı yer almaz. Hz. Ali’den farklı bir senet ile gelip Medine’nin haremliği kısmına temas etmeyen diğer sahîfe rivayetleri için bk. Ahmed b. Hanbel, el-Müsned, II, 170, 369. 
Vekî‘ b. Cerrâh'tan Muhammed b. Selâm el-Bîkendî aracılı̆g ile rivayeti alan Buhârînnin el-Câmiu's-sahîh'inde ikinci kısım müphem iken aynı rivayeti Ebû Saîd el-Eşec aracılı̆̆g ile Vekîden alan Müslim’de ikinci sınır "Sevr" şeklinde açıktır. Ayrıca Müslim bu rivayeti "Ali b. Hucr $\rightarrow$ Ali b. Müshir" kanalıyla yine A'meş'ten naklettiği bir isnatla birlikte zikretmektedir. Özellikle birkaç hocasından birden aldığı rivayetlerde metinlerde ve eda sîgalarında meydana gelen farklılıklara temas etme özelliği ile öne çıkan Müslim’in burada, diğer farklılıklara temas etmekle birlikte, rivayetin ilgili kısmı hakkında sessiz kalması dikkat çekicidir.

Rivayet dokuz ayrı kaynakta Süfyân es-Sevrî̀den gelir ve sadece Buhârînin eserinde ikinci sınır kezâ ile ifade edilir. Söz konusu rivayete, Muhammed b. Kesîr'den, Buhârî ile birlikte Ebû Dâvud ve Fazl b. Hubâb aracıllğı ile İbn Hibbân da yer vermekte ancak farklılık sadece Buhârî̀de müşahede edilmektedir. Aynı durum Abdurrahman b. Mehdînnin talebeleri arasında da tekrarlanmaktadır. Rivayeti doğrudan İbn Mehdîdden alan Ahmed b. Hanbel ile hocaları vasıtasıyla İbn Mehdîye ulaşan Müslim ve İbn Hibbân’nn eserlerinde hadis Sevr lafzı ile tahriç edilmişken Buhârî̀de ikinci sınır yine müphemdir.

İsnat şemasında dikkat çeken zincirlerden biri de Hafs tarikidir. Zira rivayeti Hafs b. Glyâs'tan oğlu Ömer b. Hafs aracılı̆ğ ile alan Buhârî ikinci sınırı müphem kaydetmekteyken hadisi Ömer b. Hafs'tan Fehd b. Süleyman vasitasıyla alan Tahâvî "Ayr-Sevr" şeklinde zikreder. Hadisi Hafs'tan oğlu Ömer yerine Muhammed b. Abdullah b. Nümeyr el-Hemdânî vasitasıyla alan Abdullah b. Ahmed b. Hanbel de ikinci sınırı Sevr olarak açık şekilde kaydetmektedir.

Tabakat-rical kaynaklarında hadisin râvileri hakkında "metinlerde veya isnatlarda kasten değişiklik yaptıkları" şeklinde veya bu bağlamda yorumlanabilecek herhangi bir değerlendirme tespit edilememektedir. Kādî İyâz ve İbn Hacer, kasitlı veya kasıtsız, problemi hadisin râvilerine atfetseler de eldeki verilere göre herhangi bir râvi öne çıkmamaktadır. ${ }^{110}$

110 Buhârî̀, Muhammed b. Beşşâr ve Muhammed b. Sellâm'dan hadisi tek başına ve ikinci sınırı müphem olarak almaktadır. Bu iki ismin kasıtlı kasıtsız rivayette bir tasarrufları düşünülebilir. Ancak Muhammed b. Kesîr ve Ömer b. Hafs b. Gıyâs aracıllı̆̆ ile kayıtlı olan ikinci sınırın müphem zikredildiği rivayetler için böyle bir şey düşünülemez. Zira isnat şemasında da görüldügü üzere bu iki isimden hadisi başka musannifler de almış olup Buhârînin hilâfına ikinci sınırı açıkça kaydetmişlerdir. Yani tespit edilebilecek cerh ifadelerinden yola çıkarak hadisin ilgili kısmındaki değişikliğin $\mathrm{Mu}-$ hammed b. Kesîr veya Ömer b. Hafs b. Giyâs'tan kaynaklandığı söylenemez. Aksi durumda bu isimlerden hadisi alan Müslim, Ebû Dâvud gibi musannifler için bu defa da müphem ifadeyi Sevr şeklinde açıkça kaydettikleri şeklinde yine bir tasarruf ihtimali karşımıza çıkacaktır. 
Şu durumda veriler, hadise yer veren bütün musannefat içerisinde, ikinci sınıra müphem olarak yer vermekte tek kalan Buhârî̀ye işaret etmektedir. Yukarıda bu doğrultuda bazı tenkitler zikredilmişti. Ayrıca hocaları veya çağdaşlarının hadisteki ikinci sınır hakkındaki görüşlerinin yanı sıra bizzat Buhârînin de bu ikinci sınırın Sevr olarak zikredilmesini vehim olarak değerlendirdiği nakledilir. Bu, el-Câmiu's-sahîh'in en önemli nüshalarından birine sahip Radıyyüddin es-Sâgānînin (ö. 650/1252), ${ }^{111}$ nüshasının kenarında aktardığı bir notta ifade edilmektedir. Sâgānî nüshasında bulunan ve Firebrî̉nin (ö. 320/932) tashih ettiği, "Bağdat nüshası" olarak bilinen nüshadaki bu notta Buhârî, hadisi aktaran "A'meş'in Sevr dediğini ve hata ettiğini" belirtir. ${ }^{112}$ Yani rivayet A'meş’e kadar Sevr şeklinde açık olarak nakledilmiştir. Buhârî Sevr'in hatalı olduğunu düşünmektedir. Bu da iki ihtimali ortaya çıkarır: İlki el-Câmiu’s-sahîh'teki "kezâ" ifadelerinin failleri, Buhârînnin, tespit edilebilen ilk tenkitlerle muasır olan hocalarıdır. Bu durumda Buhârî hadisi işittiği gibi eserine almış, A'meş’ten sonra metinde meydana gelen olası tasarrufları uygun görmüş ve -aldığı metne sadık kalmak adına- bunlara göz yummuş olacaktır. Ancak isnat tablosu üzerinden yaptığımız değerlendirmeler neticesinde herhangi bir râvinin bu rivayette bir dahlinin olmadığ 1 ortaya çıkmıştı. İkinci ihtimal ise Sevr olarak aldığı hadise bizzat Buhârînin kendisinin müdahalede bulunmuş olmasıdır. Burada da akla şu soru gelmektedir: Eleștirilere ilâveten Buhârînnin kendi ifadeleri de işin içine katıldığında, mademki Buhârî Sevr üzerinde birtakım müdahalelerde bulundu, niçin bunu ilgili hadisin bütün metinleri üzerinde yapmadı da Kitâbü’l-Ferâiz'deki hadis, açıkça Sevr şeklinde eserde kendine yer buldu? ${ }^{113}$ Zira Buhârî rivaye-

111 Hakkında bk. Zehebî, A 'lâmün-nübelâ’, XXIII, 282-84; Görmez, "Sâgānî, Radıyyüddin”, s. 487-89; Aydın, "Sahîh-i Buhârî Nüshalarına Dair Yeni Bulgular II", s. 11-17. İmam Buhârînnin yaşadığı dönemde yazıldığını ve Buhârînin talebesi Firebrînin tashih kaydını içerdiğini ifade ettiği mühim bir Sahîh-i Buhârî nüshasına vâkıf olan Sâgānînin, kendi nüshasını bu nüshayla ve başka nüshalarla da karşılaştırıp müşahede ettiği nüshalar arasındaki lafız farklılıklarını yansıtma gayretine giriştiği ve esas aldığı nüshalar için rumuzlar belirleyerek bahsi geçen farklılıklara titiz bir şekilde işaret ettiği ifade edilmiştir. Sagānî nüshasını diğerlerinden farklı kılan özelliğinin Firebrînnin tashih ettiği ve "Bağdat nüshası" olarak bilinen nüshaya dayanması itibariyle Firebrîden sonra oluşan nüshalar arasındaki birtakım farklılıkları bizzat Buhârînnin veya Firebrînin notlarıyla çözüme kavuşturması olduğu belirtilmiştir (Aydın, "Sahîh-i Buhârî Nüshalarına Dair Yeni Bulgular II”, s. 17; ayrıca bk. a.mlf., Sagânînin Sahîh-i Buhârî Nüshası ve Türkiye Kütüphanelerindeki Yazmaları [uzmanlık tezi], Türkiye Yazma Eserler Kurumu Başkanlığı, 2016).

112 Aydın, "Sahîh-i Buhârî Nüshalarına Dair Yeni Bulgular II", s. 28, 46. İfade şu

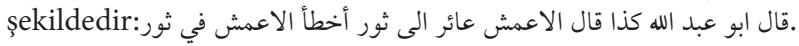

113 Problemin râvilerden kaynaklanması durumunda Buhârînin bu tek Sevr rivayetine yer vermekle farklı amaçlar taşıdığı düşünülebilirdi. İlk olarak Buhârî, Sevr şeklinde açı olarak bu tek rivayete yer vermekle, diğer rivayetlerde müphem gelen ikinci 
tin metninde kasttlı bir müdahalede bulunduysa bunun ilgili bütün rivayetlerde olması beklenirdi.

Kaynakların verdiği bilgilere göre el-Câmiu's-sahîh'te bu ikinci sınırın Sevr şeklinde açıkça kayıtlı olup olmadığı konusu ihtilâflı olduğu gibi kayıtlıysa da bunun hangi kitapta olduğu hususu da ihtilâflıdır. Bu durum hadisin ilgili kısmındaki farklılıklar için bir başka noktaya işaret etmektedir: Müstensihler ya da nüsha râvileri. Buhârînnin açıklaması ${ }^{114}$ ve diğer âlimlerce ortaya atılan tenkitler doğrultusunda, hadisin Sevr şekliyle hatalı olduğunu düşünen Buhârînin müstensihleri hadisin metnine müdahalede bulunmuşlardır.

Buhârî nüshaları arasında hadislerin sıhhatine, eserin güvenilirliğine tesiri olmayan birtakım farklılıkların olduğu belirtilmiştir. Nitekim bu farklılıkları belirten ve ortadan kaldırmayı amaçlayan çalışmalar da erken dönemden itibaren yapılagelmiştir. ${ }^{115}$ Ele aldığımız sahîfe rivayeti hakkında tespit ettiğimiz bazı ifadeler, söz konusu hadiste geçen Sevr ifadesinin, nüshadan nüshaya farklılık arzettiğini göstermekte, dolayısıyla müstensihlerin metne müdahalede bulunmuş olabileceğini düşündürmektedir. Bu noktada Buhârîde açık olarak kayıtlı Sevr'in daha sonra müstensihlerce tasrih edilmiş olup olmadığı veya "kezâ" şeklindeki rivayetlerin fâilinin müstensihler olup olmadığı tetkik edilmeye çalışılacaktır.

sınırın Sevr olduğunu açılkamak amacını taşımış olabilirdi. Ancak bizzat kendisinin, Sevr şeklinin hatalı olduğunu söylemesi bu ihtimali devre dışı bırakmaktadır. Diğer bir ihtimal ise Buhârî "Ayr-kezâ" rivayetleri yanında "Ayr-Sevr" rivayetine yer vermekle bu ikinci rivayetin illetli olduğunu göstermeyi amaçlamış olabilirdi. Zira Buhârînin, eserinde takip ettiği böyle bir âdeti olduğundan bahsedilir (İbn Teymiyye, Mecmûu fetâvâ, I, 256; Süyûtî, Tedrî̉ürr-râvî, II, 149-50). O isnadında yahut metninde ihtilâf bulunan bazı hadislere farklı şekilleriyle yer verip bunlar arasından hangisinin doğru olduğunu açıklamış ya da rivayetin muhtelif şekillerine yer vererek bir problem bulunduğuna işaret etmek istemiştir. Burada Buhârînnin sahîfe rivayeti hakkında herhangi bir açıklaması bulunmaz. Ayrıca görüleceği üzere metnin ilgili kısmına dair nüshalar arası farklar da Buhârînin böyle bir amacı gütmüş olma ihtimalini devre dışı bırakmaktadır.

114 Buhârînnin bazı izahlarının nüsha farklarına sebep olması hakkında bk. Albayrak, Buhârî Sonrası el-Câmi'u's-Sahîh, s. 15-17.

115 Meselâ bk. Ebû Ali el-Gassânî, Takyîdül-mühmel ve temyîzül-müşkil, nşr. Ali b. Muhammed el-İmrân - M. Azîz Şems, I-III, Mekke: Dâru âlemi'l-fevâid, 1421/20oo; Kādî İyâz, Meşâriku'l-envâr; Albayrak, Buhârî Sonrası el-Câmi'u's-Sahîh. Ebü'l-Velîd el-Bâcî (ö. 474/1081) gibi nüshalar arasında ciddi farklar olduğunu savunan âlimler yanında İbn Hayr el-İşbîlî (ö. 575/1179) gibi bu farkların ciddi olmadığı kanaatinde olan âlimler de vardır (Sezgin, Buhârînin Kaynakları, s. 167-68). Humeydînin (ö. 488/1095) "maymunların recmi rivayetinin Buhârînin bazı nüshalarında bulunmadığı, bunun el-Câmiu's-sahîh'e sonradan sokuşturulan hadislerden olduğu” yönündeki ifadesi ve İbn Hacer'in buna cevabı için bk. Fethu'l-bârî, VII, 160. 
İbn Hacer, Fethu'l-bârîde isim vermeden, "Buhârî rivayetlerinin tamamı ikincisini müphem bırakma hususunda müttefiktirler. Müslim'de ise 'ilâ Sevr' olarak kayıtlıdır" ifadelerini aktarır. ${ }^{16}$ Aynî, aynı ifadeleri "Ben derim ki" diyerek nakleder. ${ }^{117}$ Kastallânî de bunu tekrarlar. ${ }^{118}$ Burada söz konusu rivayetin bütün tariklerinin "ilâ kezâ" şeklinde geldiği söylenir. Ancak Yûnînî nüshasına göre tabedilmiş elimizdeki Buhârî baskılarında bir yerde Sevr'in açıkça kaydedildiği görülür. İbn Hacer "Buhârînin kasıtlı olarak ikinci sınırı müphem bıraktığı" şeklindeki eleştiriye cevap verirken "Buhârînin "Cizye" bölümünde bu hadise yer verdiğini ve Sevr'i açıkça zikrettiğini” belirtir. ${ }^{119}$ Ancak Buhârînnin Sevr’i açık olarak kaydettiği yer Yûnînî nüshasının esas alındığ̣ elimizdeki baskılara göre "Cizye" bölümünde değil "Ferâiz" bölümündedir. "Cizye" kitabında kayıtlı her iki rivayette de ikinci sınır "كذ" şeklindedir. Bu, İbn Hacer’ in hâfızasından verdiği bir anlık cevap sonucu ortaya çıkmış bir hata olabileceği gibi şerhinde kullandığı/gördüğg̈ nüshalar ile adı verilmeyen söz konusu tenkidin sahibinin, Aynînnin ${ }^{120}$ ve elimizdeki baskıların dayandığı nüshaların, hadisin ilgili kısmında, farklılıklar taşıdığına da işaret edebilir.

Şerhinde Yûnînî nüshasını esas almakla birlikte çeşitli nüshalar arasındaki farklılıklara dair verdiği bilgilerle öne çıkan Kastallânî, "Ferâiz" bölümündeki ilgili rivayette, "Ebû Zer nüshasında 'ilâ Sevr' yerine 'ilâ kezầ ibaresinin bulunduğunu" söyler. ${ }^{121}$ Ebû Zer rivayeti esas alınarak gerçekleştirilmiş bir baskıda da "Ferâiz" kitabındaki söz konusu rivayetin ikinci sınırı "kezâ" şeklindedir. ${ }^{122}$ Esasında bu baskıda ilgili rivayetin bütün tariklerinde ikinci sınır müphem olarak takdim edilmiştir. Sagānî nüshasında da Ferâiz kitabındaki bu rivayetin "ilâ kezâ" şeklinde kayıtlı olduğu belirtilmiştir. ${ }^{123}$

116 İbn Hacer, Fethu'l-bârî, IV, 98.

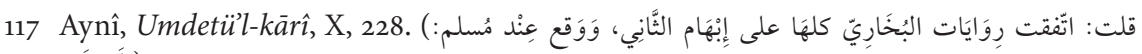
(إلَى ثَوْرَ

118 Kastallânî, İrşâdü's-sârî, X, 320.

119 İbn Hacer, Fethu'l-bârî, IV, 99.

120 "Cizye" kitabında kayıtlı (Muhammed b. Sellâm'dan gelen) "min Ayr ilâ kezâ" rivayetindeki kezâ hakkında söylediği "Uhud olabilir" ifadelerinden hareketle Aynînin kullandığı nüshada da "Cizye” kitabında Sevr'in müphem olarak yer aldığı anlaşılır (Umdetü'l-kārî, XV, 94). "Cizye” bölümündeki Muhammed b. Kesîr'den gelen diğer rivayet de Umdetül-kärî̀de "kezâ" şeklindedir (XV, 102).

121 Kastallânî, İrşâdü̉s-sârî, X, 441. Yûnînî nüshasına göre tabedilmiş bazı Sahîh-i Buhârî baskılarında, "Ferâiz" kitabında kayıtlı bu rivayetin kenarına, metni tashih etme anlamında bir sah ifadesi düşülmüş ve Ebû Zer nüshasında "ilâ kezâ" şeklinde olduğu belirtilmiştir (el-Câmiu's-sahîh [Muhammed Züheyr], VIII, 158).

122 el-Câmiu's-sahîh lìl-Buhârî min rivayeti (Abdülkādir Şeybe), III, 590.

123 Aydın, "Sahîh-i Buhârî Nüshalarına Dair Yeni Bulgular II", s. 28, dn. 62. 
Ebû Muhammed el-Asîlînin (ö. 392/1002) talebelerinden olan ve şerhinde de Asîlî nüshasını esas alan Mühelleb b. Ebû Sufre, Hafs b. Gıyâs’ın "ilâ kezâ"; Muhammed b. Kesîr' in ise "ilâ Sevr" dediğini belirtir. ${ }^{124}$ Yani rivayet Asîlî nüshasındaki "Cizye" bölümünde İbn Hacer’in işaret ettiği gibi açık olarak kayıtlıdır.

İbn Hacer'in hocalarından Muhammed b. İbrâhim b. İshak el-Münâvî (ö. 803/1401) konuya dair şunları söyler:

Bu hadisi İbn Mâce dışında Kütüb-i Sitte müellifleri eserlerine ${ }^{125}$ almış, Tirmizî hariç diğerleri rivayeti burada [Kitâbü’l-Menâsik, bâbu haremi'lMedîne] zikretmişlerdir. Tirmizî ise "Hibe" ve "Velâ" babında, Hz. Ali'den zikretmiştir. Buhârî̂ "ilâ Sevr" dememiştir; bütün tariklerinde "ilâ kezâ" demiştir. Ebû Muhammed el-Asîlî rivayeti hariç. Onda "Cizye" ve "Muvâzaa" kitabında "ilâ Sevr" şeklinde vâkidir. ${ }^{126}$

Buradan anlaşıldığına göre Aynî ve "İkinci sınırların tamamı müphemdir” diyen diğer âlimler, Asîlî nüshasını görmemiştir. İbn Hacer ise ya söz konusu nüshayı görmüştür ya da bu bilgiyi hocasına dayanarak vermiştir. ${ }^{127}$

Yani a) bütün rivayetlerde ikinci sınırı müphem olarak nakleden bir nüsha (Ebû Zer nüshası), b) "Cizye" kitabında ikinci sınırın açık olarak geldiği bir nüsha (Asîlî nüshası) ve c) "Ferâiz" kitabında ikinci sınırın açı olarak geldiği bir nüsha (Yûnînî nüshası) ${ }^{128}$ olmak üzere üç farklı durum ortaya çıkmaktadır. Bu durumda Buhârînin bir tek rivayeti de olsa açık olarak kaydettiğini söyleyip onun rivayetin ilgili kısmında tasarrufta bulunmadığını söylemek veya Buhârînin hepsini müphem kaydettiğinden bahsetmek isabetli olmayacaktır. ${ }^{129}$ Zira bizzat Buhârî tarafından Sevr'in açık olarak kaydedildiği bir rivayet var mıdır, varsa hangisidir, bu husus net değildir.

124 Mühelleb b. Ebû Sufre, el-Muhtasarünn-nasîh, III, 26.

125 Söz konusu rivayet Nesâînin el-Müctebâ’sında değil es-Sünenü’l-kübrâ’sında nakledilmektedir.

126 Münâvî, Keş̧ü̉l-menâhic, II, 442-43.

127 Dolayısıyla İbn Hacer'in "Cizye” kitabında rivayetin Sevr şeklinde olduğunu belirtmesi hata değildir.

128 Yûnînî, nüshasını oluştururken Ebû Zer, Asîlî, Ebü'l-Vakt (ö. 553/1158) ve İbn Asâkir (ö. 571/1176) olmak üzere dört nüshayı esas almıştır (Sezgin, Buhârînin Kaynakları, s. 183). Buradan hareketle Yûnînînin "Ferâiz" kitabında ikinci sınırı Sevr olarak kaydetmesinin Ebü'l-Vakt veya İbn Asâkir nüshalarından kaynaklandığı söylenebilir.

129 Rif'at Fevzî Abdülmuttalib, İbn Hacer'in Buhârî hakkındaki mülahazalarını aktarır, Cizye kitabına işaret etmesine hiç değinmez ve "Ferâiz" kitabındaki açık Sevr lafzından hareketle Buhârî̀ye yöneltilen eleştiriyi geçiştirmeye çalışır (Sahîfe, s. 29-30). 
Buhârî, A'meş'in Sevr dediğini ve bununla hata ettiğini belirttikten sonra bu ikinci sınırı eserine nasıl almıştır? Herhangi bir râvinin müdahalesinden bahsedemiyorsak ya Buhârî bu hadisi bütün hocalarından Sevr olarak almış, eserine öyle kaydetmiş, tenkitler ve Buhârînnin açıklaması doğrultusunda müstensihlerin bazısı bunu "kezâ" yapmıştır. Ya da Buhârî hocalarından Sevr olarak dinlemiş ancak eserine alırken bunu "kezâ" yapmış veya Sevr'in yerini boş bırakmış, müstensihlerden kimi bunu Sevr olarak tasrih etmiş, kimi boşluğu Sevr ile doldurmuş, bazısı da herhangi bir müdahalede bulunmamıştır. Rivayetin nüshadan nüshaya farklılık göstermesinin sebebi de bu her iki durumdaki olası müstensih müdahaleleridir.

Asîlî nüshasının "Cizye" kitabındaki ikinci sınırın açık olarak nakledildiği hadisten hareketle Buhârî̀deki ilgili hadisin bütün tariklerinin müphem olmadığı ve tabii olarak bu tasarrufu yapanın Buhârî olmadığ neticesine ulaşılabilirdi. Ancak meselenin Asîlî nüshası ile açıklanması yeterli görünmemektedir. Zira Kādî İyâz Meşâriku'l-envâr'da şöyle demektedir:

İbnüs-Seken'in Kitâbü'l-Cihâd’ında "Ayr'dan Sevr'e” șeklindedir. Bu hadisin tamamıdır. Asîlîde Ayr'dan sonrası boş bırakılmıştır. Diğer râvilerde "ila kezâ" şeklindedir. Sevr'in burada vehim olduğunu söylemişlerdir. Bundan dolayı bazıları onu düşürmüş bazıları ise ["kezâ" şeklinde] müphem hale getirmiştir. ${ }^{130}$

Buhârî baskılarında "Kitâbü'l-Cihâd"da söz konusu rivayet yer almaz. Muhtemelen o, "Kitâbü'l-Cizye"deki rivayetten bahsetmektedir. Nitekim aynı eserinde naklettiği şu ifadelerinden bu husus anlaşılmaktadır:

Buhârîde Hz. Ali hadisinin Muhammed b. Kesîr rivayetinde ["Cizye", 17] "Ayr'dan Sevr'e" șeklindedir. Yine İbnü’s-Seken nüshasında Vekî‘ rivayetinde ["Cizye", 10] ve Cürcânîde de [ö. 373/983] de böyledir. [Ebû Zeyd] el-Mervezî ise [ö. 379/989] ise üzerine çizgi çekmiştir. Müslim’deki A'meş rivayetinde [yani bütün rivayetlerde, ikinci sinır Sevr olarak] sabittir. Nesefîdeki [ö. 295/908] Ali hadisinde ve Ebû Nuaym’da [el-İsfahânî (ö. 430/1039)] Sevr yerine “ila kezâ" şeklindedir. ${ }^{131}$

Ayrıca Ebû Zer rivayeti esas alınarak yapılmış neşirde "Kitâbü'l-Humus" ile birlikte "Kitâbü'l-Cizye" bölümü "Kitâbü'l-Cihâd"ın birer babı olarak geçmekte olup müstakil bölüm değillerdir. Dolayısıyla her iki açıklamada kastedilen rivayet aynıdır.

130 Kādî İyâz, Meșâriku'l-envâr, II, 390.

131 Kādî İyâz, Meşâriku’l-envâr, I, 136. 
Kādî İyâz’̉n gördüğü Asîlî nüshasında Sevr’in yeri boşken, Münâvînin gördüğü Asîlî nüshasında boşluktan bahsedilmez ve sınırın Sevr olarak kayıtlı olduğu söylenir. Kādî İyâzz bu ikinci açıklamasında Mervezî nüshasında Sevr'in üzerine çizgi çekildiğini söyler. Cürcânî ve Mervezî nüshalarını bir araya getirmeye çalışan ve daha çok Mervezî nüshasına itibar eden Asîlînnin ${ }^{132}$ Sevr'in yerini boş bırakma sebebi muhtemelen Mervezînin bu tasarrufudur.

İbnü's-Seken (ö. 353/964) nüshasındaki açık olarak kayıtlı Sevr rivayetinden ${ }^{133}$ hareketle de tasarrufu yapanın Buhârî olmadığı sonucuna ulaşılabilirdi. Ancak bizzat İbnü’s-Seken’in Buhârîde geçen muğlak/müphem bırakılmış pek çok ismi açıklaması, ${ }^{134}$ benzer bir müdahaleyi burada da akla getirecektir.

Buhârî tarafından müphem bırakılmış ifadelerin daha sonra müstensihlerce tasrih edilmiş olduğuna dair örnekler yanında bizzat Buhârî tarafından rivayetin metninde boş bırakılan bir yerin müstensihler tarafından doldurulması ve Buhârînin bu sahîfe hadisinde de şüpheli gördügü yeri boş bıraktığ 1 şeklinde eleştirilmesi akla şu soruyu getirecektir: Acaba burada da nüshalar arasındaki farklar, özellikle Sevr’in açık olarak kaydedilmesi, Buhârî tarafından müphem olarak kaydedilen yahut yeri boş bırakılan bu ifadenin daha sonra kimi müstensihlerce tasrih edilmesinden, yerinin doldurulmasindan mı kaynaklanmaktadır?

Bu iki ihtimal dikkate alındığında, Buhârî̀deki bütün tariklerin müphem olarak kayıtlı olduğu yönündeki tenkidin doğruluk payının bulunabileceği akla gelmektedir. Bu durum Buhârînnin, hata olduğunu düşündüğü için, kasten ikinci sınırı Sevr olarak eserine almadığı sonucuna götürecektir. Ancak bu neticeyi engelleyen bazı hususlar vardır: Buhârînin bazı izahlarının müstensihler tarafından metne çekilmesi; müstensihlerin Buhârî̀den sehven kaynaklandığını düşündükleri hataları düzeltme görevini üstlenmeleri; ${ }^{135}$ müstensihlerin Sevr ifadesinin üzerine çizgi çektiklerine dair açık ifadeler. $\mathrm{Bu}$ hususlardan hareketle müstensihlerin bu ikinci sınırı "kezâ" yapabilme ihtimalleri Buhârî hakkındaki eleștirilerde ihtiyatlı olmayı gerektirmektedir.

132 Albayrak, Buhârî Sonrası el-Câmi'u's-Sahîh, s. 7.

133 Kādî İyâz’nn yukarıdaki açıklamalarının yanı sıra bk. İbn Battâl, Şerhu Sahîhi’l-Buhârî, IV, 537 ("Bu 'kezẩ lafzı, Sahîh-i Buhârînin bazı temel nüshalarında ve İbnü’s-Seken rivayetinin bazı kitaplarında "Ayr'dan Sevr'e” şeklinde vâkidir").

134 Buhârî tarafından muğlak (müphem) bırakılmış bir adın İbnü’s-Seken tarafından tasrih edilmesine dair bk. Sezgin, Buhârînin Kaynakları, s. 191; benzer bir örnek için bk. Özsoy, Buhârî Nüshaları, s. 87.

135 Nüsha râvilerinin tashih amaçlı müdahalelerine örnekler için bk. Özsoy, Buhârî Nüshalarl, s. 215-19. 
Müstensih müdahalesi Ahmed b. Hanbel'in el-Müsned'i ve Müslim'in elCâmiu's-sahîh'i için de geçerlidir. Bazı şerhlerde rivayetin Ayr-Uhud şekline atıf yapılırken Taberânî ile birlikte Ahmed b. Hanbel de zikredilir. ${ }^{136}$ Oysa görüldüğü üzere el-Müsned'de ikinci sınır Uhud iken ilk sınır "kezâ" şeklindedir. Bu durumun, Sevr yanında Ayr dağının Medine'de bulunmadığ yönündeki tenkitlerin bir sonucu olarak daha sonra müstensihlerin metne bir müdahalesi neticesinde gerçekleştiği düşünülebilir. Mâzerî, Müslim nüshalarının bazısında " إلى ثور" 'yerine "ifadesinin bulunduğunu söyler. Müslim'de ikinci sınırların tamamının Sevr şeklinde açık olduğu görülür. Burada Sevr'in hatalı olduğunu düşünen müstensihlerin ifadeyi müphem hale getirdiği söylenebilir. Bu da benzer müstensih müdahalesinin Müslim’in el-Câmiu's-sahîh'i için de geçerli olduğuna işaret etmektedir.

Buhârînin eserini telif süreci dikkate alındığında söz konusu farklılıkların Buhârînin, eseri üzerinde daha sonra yaptığ değişikliklerden kaynaklandığg düşünülebilir. Ancak bu hususta Buhârînnin ne gibi değişiklikler yaptığgna dair kaynaklarda bir kanaate ulaştıracak bilgi bulunmamaktadır. ${ }^{138}$

Sorulması gereken bir diğer soru da Buhârî̉nin, A'meş'in Sevr dediğini ve bununla hata ettiğini belirttikten sonra tenkit edilmiş bu rivayeti eserine niçin aldığıdır? Buhârîde kayıtlı rivayetler isnat açısından herhangi bir problem ihtiva etmemektedir. Bu durum Buhârînnin, isnadını yeterli bulduğu bir rivayeti metninde problem bulunsa da eserine almayı uygun gördügü sonucuna götürecektir. Ancak ihtilâflı olan, tenkit edilmiş ilgili kısmın rivayetin mânasına etki edecek; zayıf sayılmasını, tahriç edilmemesini gerektirecek bir durum arzetmediği için onun böyle davranmış olduğu söylenebilir. Nitekim Buhârînin el-Câmiu's-sahîh'inde benzer örneklerin bulunduğu ve bunların herhangi bir problem teşkil etmeyeceği belirtilmiştir. ${ }^{139}$

\section{Değerlendirme ve Sonuç}

Erken dönemden itibaren, Medine’nin harem bölgesinin sınırlarını Ayr dağı ile Sevr dağı arasında kalan bölge olarak belirten rivayete, Medine'de bu isimde dağların, özellikle Sevr adında bir dağın bilinmediğinden hareketle eleştiriler yöneltilmiştir. Eleştirilerin söz konusu hadis üzerindeki yansımalarını tespit etmeyi amaçlayan bu çalışmada öncelikle Medine’de adı geçen

136 İbn Hacer, Fethu'l-bârî, IV, 82; Aynî, Umdetü'l-kārî, X, 228; Azîmâbâdî, Avnü’l-ma'bûd, VI, 13; Şinkîtî, Kevserü'l-maânid-derârî, XIV, 204.

137 Mâzerî, el-Mu'lim, II, 117.

138 Sezgin, Buhârînin Kaynakları, s. 170.

139 Bilen, İbn Hacer'in Buhârî Savunusu, s. 337-41. 
dağların mevcudiyeti tetkik edilmeye çalışılmış, Medineli isimlerin ve Medine şehrine has kaynakların verdiği bilgilerin neticesinde tenkitlerin isabetsiz olduğu anlaşılmıştır. Zira ispat nefye mukaddemdir. Medine şehri ile özel olarak ilgilenmiş, bu şehre dair eser kaleme almış âlimlerin, Sevr dağının varlığına dair verdikleri bilgiler karşısında, Medine ehlinden bir kısım insanın bu dağ Mekke'de şöhret bulmuş olmasının, ilâveten Uhud dağının da Medine'de meşhur olup arkasında kalan küçük Sevr’i gölgelemiş olmasının, ayrıca rivayetlerdeki Medine-Uhud vurgusunun tenkitte bulunan Ebû Ubeyd ve diğer âlimleri yanıltmış olabileceği düşünülebilir.

Her ne kadar isabetsiz de olsa Sevr (ve Ayr) üzerinden rivayete yöneltilen tenkitler rivayetin toptan zayıf yahut asılsız görülmesine değil zorlama yorumlara ve eleştiriler doğrultusunda rivayetin metni üzerinde birtakım tasarruflara sebep olmuş veya böyle bir ithamı gündeme getirmiştir. Bu noktada hadis edebiyatında benzer örneklerin olup olmadığının tetkik edilmesiyle rivayetlere yöneltilen eleştirilerin -hadisin rivayeti, kitaplara kaydı, şerhi ve kayıtlı olduğu kitabın istinsahı/nakli gibi muhtelif aşamalarda- hadis metinleri üzerindeki yansımaları takip edilebilir. ${ }^{140}$

Kaynaklardan hareketle Mekke'de olduğu gibi Medine'de de Sevr adında bir dağın olduğunun ortaya konmasıyla, Mekke'deki Sevr dağı dikkate alınarak hadis hakkında yapılan zorlama yorumların isabetsiz olduğu anlaşılmıştır.

140 Bununla hadis metinlerine râvilerin inançları, itikadî veya fikhî görüşleri muvacehesinde müdahalelerini kastetmiyoruz. Bu yönde bir çalışma için bk. Erul, "Tasarrufâtürr-ruvât". Burada kastedilen ise rivayetin metninin, tenkitlere sebep olan kısımdan ya tamamen izâlesi yahut metin üzerinde tenkidi bertaraf edecek, geçiştirecek bazı tasarrufların ortaya konmasıdır. Buna Ebû Ubeyd'in Kitâbül-Emvâl'inde ve İbn Ebû Şeybe’nin el-Musannef inde yer verdiği şu rivayet örnek gösterilebilir. Huzeyfe b. Yemân ile Sehl b. Huneyf’in (ö. 38/658-59) Hz. Ömer tarafından cizye toplama konusunda görevlendirildiğine işaret eden rivayet hakkında Ebû Ubeyd, "Çokları rivayette geçen ismi böyle, 'Sehl b. Huneyf' şeklinde nakletmiştir. Ancak bu adın doğrusu 'Osman b. Huneyf' olmalıdır” notunu düșer (Kitâbü'l-Emvâl, s. 120). Hz. Ömer'in haraç ve cizye toplama görevi ile Irak’a gönderdiği isim, kaynaklarda, aynı zamanda Sehl'in kardeşi olan, Osman b. Huneyf (ö. 41/661?) olarak geçer (Hz. Ömer'in Huzeyfe ve Osman b. Huneyf'i cizye toplama görevi ile gönderdiğine dair farklı rivayetler bulunmaktadır. Rivayetler için bk. Buhârî̀, "Ashâbü’n-nebî”, 8; Abdürrezzâk es-Sanânî, el-Musannef, VI, 103; İbn Hibbân, Sahîh, XV, 350. Osman b. Huneyf hakkında bk. İbn Abdülber, el-İstîâ, III, 1033; Hatîb, Târîh, I, 531). Benzer rivayetlerde bu ismi Osman b. Huneyf olarak kaydeden İbn Ebû Şeybe, Ebû Ubeyd'in naklettiği bu hadisi aynı isnatla ihtisaren aktarır ve "İbn Huneyf" demekle yetinir. Bu durum, farklı ihtimalleri de (meselâ ihtisar) düşündürebileceği gibi, İbn Ebû Şeybe’nin, Ebû Ubeyd vb. âlimlerin tenkitlerinden ya da rivayetin doğru şeklinden haberdar olup bu doğrultuda rivayete bir müdahalede bulunmuş olabileceğini akla getirmektedir. 
Çalışmada söz konusu hadisin bütün tarikleri bir araya getirilmiş ve hadisin metninin ilgili kısmında bir problem/tasarruf olduğu görülmüştür. $\mathrm{Bu}$ durumun kimden kaynaklandığı noktasında akla gelecek ilk ihtimal râvilerin zabt problemi olmalıydı. Ancak her ne kadar bazı âlimler tarafından bu husus dile getirilse de tenkitler "kasıtlı müdahale" noktasında yoğunlaşmıştır.

Bu kasıtlı müdahalenin sahibinin ilk olarak râviler olma ihtimali üzerinde durulmuştur. Hadisi rivayet eden râvilerin tenkitlerden etkilenerek veya kendi bilgileri doğrultusunda (burada büyük çoğunluğunun Iraklı olduğu hatırlanmalıdır) metin üzerinde tasarrufta bulundukları düşünülebilir. Nitekim bu minvalde tenkitler de bulunmaktadır. A'meş'e kadar, "Sevr" kelimesinin açıkça ifade edilmesi suretiyle gelen rivayet, kitaplara kaydedilene kadar geçen süreçte bazı tasarruflara mâruz kalmış olabilir. Ancak tespit ettiğimiz bilgilerden hareketle herhangi bir râvinin tasarrufta bulunduğundan bahsetmek mümkün değildir. Rivayette ikinci sınır üzerindeki değişikliklerin, ister kasıtlı olsun ister kasıtsız olsun, hadisin râvilerinden kaynaklandığını söyleyemeyiz.

Sadece Buhârînin el-Câmiu's-sahîh'inde "kezâ" şeklinde nakledilmesi; ortak tariklerden alınan rivayetlerde diğer musanniflere muhalif olarak Buhârînin eserinde hadisin "kezâ" olarak kayıtlı olması; Buhârînin Sevr kelimesinin bu hadiste zikredilmesinin hata olduğunu açıç̧a beyan etmesi ve bu bağlamda tenkitlerin hedefine oturması sebebiyle tasarrufun sahibinin Buhârî olma ihtimali üzerinde durulmuştur. Hadisi eserine alan bütün müelliflerin hilâfına Sevr kısmının kapalı olduğu rivayetlere yer verme hususunda tek kalan Buhârî, rivayetin metnine hem kendi düşüncesi hem de tenkitler doğrultusunda müdahil olmuş olabilir. el-Câmiu's-sahîh'te bir yerde ikinci sınırın açık olarak Sevr şeklinde yer almasından hareketle böyle bir düşüncenin isabetsiz olduğu da söylenemez. Gerçekten de söz konusu kısma bir müdahalede bulunacaksa eğer sadece bu tek rivayeti birakması anlamsız görünecektir. Fakat Sahîh'te ikinci sınırın Sevr olarak bulunup bulunmadığı tartışmalı olduğu gibi Sevr lafzı eğer açıkça kayıtlı ise bunun hangi kitapta olduğu da ihtilâflıdır. Rivayetin tartışmalı kısmının nüshadan nüshaya farklılık göstermesi Buhârî hakkındaki eleştirilere ihtiyatla yaklaşmayı gerektirmektedir.

Nüshaların hadisin ilgili kısmında farklllık göstermesi musanniften sonra eser üzerinde yapılmış bir tasarrufu akla getirmektedir. el-Câmiu's-sahîh râvilerinin/müstensihlerinin rivayetin metnine müdahale ettikleri söylenebilir. Muhtemel tek Sevr ifadesine ilâveten ilgili hadisin tartışmalı kısmındaki farklılıklar bu olası müstensih müdahalelerinden kaynaklanmaktadır. Ancak müstensihlerin bu müdahalesinin mahiyeti nedir? Bu müdahale Buhârî tarafından müphem nakledilmiş bir ifadeyi tasrih etme, yeri boş bırakılmış 
ikinci sınırı zikretme şeklinde mi yoksa Buhârînnin açık kaydettiği ikinci sınırı rivayete yöneltilen tenkitler ve Buhârînin tenkitler doğrultusundaki düşüncesinin tesiriyle ipham etme şeklinde mi vuku bulmuştur? Bu noktada müstensihlerin, Buhârînin müphem (muğlak) bıraktığı bazı râvi isimlerini açıklama çabaları ilk ihtimali akla getirse de onların Buhârî metni üzerinde tashih, ikmal amaçlı birtakım müdahalelerde bulunduklarına dair örnekler; açıkça sahîfe rivayetindeki Sevr'e müdahale ettiklerine dair ifadeler, Buhârînin bazı açıklamalarının daha sonra metne yansıtıldığına dair uygulamalar ikinci ihtimali güçlü kılmaktadır. Ayrıca Buhârî haricindeki eserlerde de, meselâ Müslim'in el-Câmiu's-sahîh'inin bazı nüshalarında, açık sınırların ipham edildiğinin belirtilmesi de bu hususu destekler.

Buna göre Buhârî̀ metne herhangi bir müdahalede bulunmamış olup eserdeki bütün "kezâ" lafızlarının fâili müstensihlerdir. Bu noktada "niçin kimi Buhârî nüshalarının bazı bölümlerinde ikinci sınırın Sevr olarak nakledile geldiği” sorusuna farklı cevaplar verilebilir. Şayet müstensihlerin bu yönde bir müdahalesi düşünülecekse bu tasarrufu bütün rivayetler üzerinde yapmaları beklenirdi.

Öncelikle kaynakların verdiği bilgilere göre Ebû Zer gibi bütün rivayetlerde ikinci sınırın "kezâ" olarak zikredildiği nüshalar bulunmaktadır. Sevr' in açık olarak ifadesi nâdiren bulunmaktadır. Bu da bazı müstensihlerin atlamış olabileceklerini gösterir. Ayrıca bir nüshada yerinin boş olduğu belirtilen s1nırın başka bir kaynak tarafından yine aynı nüshada Sevr olarak zikredildiğinin belirtilmesi de bu tek Sevr ifadesini açıklığa kavuşturma noktasında önemlidir. Muhtemelen bir müstensih tarafından boş bırakılmış olan ikinci sınırın yeri, başka müstensihlerce, rivayetin kaynaklardaki diğer tariklerinden hareketle, Sevr olarak doldurulmuştur.

Netice itibariyle başta Kāsım b. Sellâm olmak üzere âlimlerin rivayete yönelttikleri tenkitlerin hadisi eserine alan Buhârî veya el-Câmiu's-sahîh'i kopya eden müstensih üzerinde etkili olduğu ve söz konusu rivayetin elCâmiu's-sahîh'te birtakım tasarruflara uğrayarak tahriç edildiği/günümüze ulaştığı anlaşılmaktadır. Rivayete bazı zorlama yorumlar getirmeye çalışan şârihlerin de tenkitlerin etkisinde kaldığ 1 görülmektedir. Müstensihlerin herhangi bir şekilde ancak kesin olarak rivayete müdahil oldukları söylenebilir. Daha muhtemel olan Buhârî tarafından açık kaydedilmiş sınırı müphem hale getirmeleridir. Buhârî için ise aynı kesinlik söz konusu değildir.

Buhârî nüshaları arasında bir kısmı hadislerin mânalarına herhangi bir tesiri olmayan, bir kısmı da hadisin anlaşılmasını doğrudan etkileyen farklılıklar bulunmaktadır. Bu rivayet özelinde bakıldığında, söz konusu 
tasarrufların veya nüshalardan kaynaklanan farklılıkların hadisin anlamını veya sıhhatini etkileyen çok mühim farklılıklar içermemesi önemlidir. Bununla birlikte bu ve benzeri örneklerin tespiti nüsha farklılıklarının sebepleri, eserlerin intikal süreci, râvilerin/musanniflerin rivayetler karşısında takındıkları tavır, Buhârî ve eserinin bazı özellikleri gibi hususları daha sağlıklı değerlendirebilme imkânı sunacaktır.

\section{Bibliyografya}

Abdürrezzâk es-Sanânî, el-Musannef, nşr. Habîburrahman el-A'zamî, I-XI, Karaçi: elMeclisü'l-ilmî, 1390/1970.

Ağırakça, Ahmet, “Âir”, DİA, 1989, II, 200-201.

Ahmed b. Hanbel, Kitâbü’s-Sünne, nşr. Muhammed b. Saîd b. Sâlim el-Kahtânî, I-II, Demmâm: Dâru İbni'l-Kayyim, 1406/1986.

Ahmed b. Hanbel, el-Müsned, nşr. Şuayb el-Arnaût v.dğr., I-L, Beyrut: Müessesetü’r-risâle, 1416/-21/1995-2001.

Albayrak, Ali, Buhârî Sonrası el-Câmi'u’s-Sahîh: Nüsha Farklılıkları, Hatalar, Tashihler (yayımlanmamış çalışma).

Ali Hâfız, Fusûl min târîhi'l-Medîneti'l-münevvere, Cidde: Şeriketü'l-Medîneti'l-münevvere li't-tıbâa ve’n-neşr, 1417/1996.

Aydın, Arafat, "Sahîh-i Buhârî Nüshalarına Dair Yeni Bulgular II: es-Sagânî Nüshası ve Türkiye Kütüphanelerindeki Yazmaları”, Hadis Tetkikleri Dergisi, 9/1 (2016): 7-50.

Aydın, Arafat, Sagânînin Sahîh-i Buhârî Nüshası ve Türkiye Kütüphanelerindeki Yazmaları (uzmanlık tezi), Türkiye Yazma Eserler Kurumu Başkanlığı, 2016.

Aynî, Bedreddin, Umdetü’l-kārî şerhu Sahîhi'l-Buhârî, I-XXV, Beyrut: Dâru ihyâi't-türâsi'lArabî, t.y.

Azîmâbâdî, Avnü’l-ma'bûd şerhu Süneni Ebî Dâvûd, I-XIV, Beyrut: Dârü'l-kütübi'l-ilmiyye, 1415 .

Belâzürî, Fütûhu'l-büldân, Beyrut: Meketebetü'l-hilâl, 1988.

Beyhakī, Ahmed b. Hüseyin, es-Sünenüll-kübrâ, nşr. M. Abdülkādir Atâ, I-XI, Beyrut: Dârü'l-kütübi'l-ilmiyye, 1424/2003.

Beyhakī, Ahmed b. Hüseyin, Ma'rifetüss-sünen ve’l-âsâr, nşr. Abdülmutî̀ Emîn Kal'acî, I-XV, Kahire: Câmiatü'd-dirâsâti'l-İslâmiyye, 1412/1991.

Bezzâr, el-Bahrüzz-zehhâr: el-Müsned, nşr. Mahfûzurrahman Zeynullah v.dğr., I-XVIII, Medine: Mektebetü'l-ulûm ve'l-hikem, 1409-30/1988-2009.

Bilen, Mehmet, İbn Hacer'in Buhârî Savunusu, Ankara: Ankara Okulu Yayınları, 2013.

Bozkurt, Nebi - Mustafa Sabri Küçükaşcı, "Medine”, DİA, 2003, XXVIII, 305.

Buhârî̀, Muhammed b. İsmâil, el-Câmiu's-sahîh li'l-Buhârî min rivâyeti Ebî Zer el-Herevî an meşâyihihis'selâse el-Küşmîhenî ve'l-Müstemlî ve’s-Serahsî̀, I-III, nşr. Abdülkādir Şeybe el-Hamed, Riyad: Mektebetü'l-Melik Fehd el-Vataniyye, 2008. 
Buhârî, Muhammed b. İsmâil, el-Câmiu’s-sahîh, nşr. M. Züheyr b. Nâsır en-Nâsır, I-IX, Beyrut: Dâru tavkín-necât, 1422.

Buhârî, Muhammed b. İsmâil, Sahîhu'l-Buhârî, I-VIII, İstanbul: el-Mektebetüll-İslâmiyye, 1979.

Buhârî, Muhammed b. İsmâil, et-Târîhu'l-kebîr, nşr. Abdurrahman b. Yahyâ el-Yemânî v.dğr.), I-VIII, Beyrut: Dârü'l-kütübi'l-ilmiyye, t.y.

Çelikkol, Yaşar, Hicri Birinci Yüzyılda Medine Şehri (Fiziki, Demografik, İdari, İktisadi ve Sosyal Yapısı) (yüksek lisans tezi), Frrat Üniversitesi Sosyal Bilimler Enstitüsü, 1995.

Dârekutnî, el-İlelül-vâride fi'l-ehâdîsin-nebeviyye, nşr. Mahfûzürrahman Zeynullah esSilefî, I-XV, Riyad: Dâru Taybe, 1405/1985.

Ebû Avâne el-İsferâyînî, Müsnedü Ebî Avâne, nşr. Eymen b. Ârif ed-Dımaşkī, I-V, Beyrut: Dârü'l-márife, 1419/1998.

Ebû Dâvûd es-Sicistânî, Sünenü Ebî Dâvûd, nşr. M. Muhyiddin Abdülhamîd, I-IV, Beyrut: el-Mektebetü'l-Asriyye, t.y.

Ebû Nuaym el-İsfahânî, Delâilünn-nübüvve, nşr. M. Ravvâs Kal'acî - Abdülber Abbas, Beyrut: Dârün-nefâis, 1406/1986.

Ebû Ubeyd el-Bekrî, Mu'cemü me’sta'cem min esmâi’l-bilâd ve'l-mevâzi', I-IV, Beyrut: Âlemüll-kütüb, 1403/1983.

Ebû Ubeyd, Kāsım b. Sellâm, Garîbü’l-hadîs, nşr. M. Ali Beydûn, I-II, Beyrut: Dârü’lkütübi'l-ilmiyye, 2003.

Ebû Ubeyd, Kāsım b. Sellâm, Kitâbüll-Emvâl, nşr. M. İmâre, Kahire: Dârü’s-selâm, 2009.

Ebû Ya'lâ el-Mevsılî, el-Müsned, nşr. Hüseyin Selîm Esed, I-XIII, Dımaşk: Dârü’l-Me’mûn li't-türâs, 1984-86.

Erul, Bünyamin, “Tasarrufâtu’r-ruvât fî̀ mütûni'l-merviyyât", Ankara Üniversitesi İlâhiyat Fakültesi Dergisi (AÜİFD), 42/1 (2001): 173-212.

Eyüp Sabri Paşa, Mirâtü’l-Haremeyn, I-III, İstanbul: Bahriye Matbaası, 1301-1306.

Fîrûzâbâdî, el-Kāmûsüll-muhît, Beyrut: Müessesetürr-risâle, 2005.

Fîrûzâbâdî, el-Megānimül-mütâbe fî meâlimi Tâbe, nşr. Hamed el-Câsir, Riyad: Dârü’lYemâme, 1389/1969.

Görmez, Mehmet, "Sâgānî, Radıyyüddin”, DİA, 2008, XXXV, 487-89.

Hamîdullah, Muhammed, Hz. Peygamber'in Savaşları, çev. Nazire Erinç Yurter, İstanbul: Beyan Yayınları, 2015.

Hamîdullah, Muhammed, İslâm Anayasa Hukuku, ed. Vecdi Akyüz, İstanbul: Beyan Yayınlar1, 1998.

Hamîdullah, Muhammed, İslâm Peygamberi, çev. Mehmet Yazgan, İstanbul: Beyan Yayınları, 2011.

Hatîb el-Bağdâdî, el-Kifâye fî márifeti usûli ilmirr-rivâye, nşr. Mâhir Yâsîn el-Fahl, I-II, Demmâm: Dâru İbni'l-Cevzî, 1435.

Hatîb el-Bağdâdî, Târîhu Medînetis-selâm, nşr. Beşşâr Avvâd Ma'rûf, I-XVII, Beyrut: Dârü'l-garbi'l-İslâmî, 1422/2001. 
Hatiboğlu, İbrahim, "Muhibbüddin et-Taberî", DİA, 2006, XXXI, 38-39.

Hattâbî, Meâlimü’s-sünen, I-IV, Halep: el-Matbaatüll-ilmiyye, 1351-53/1932-34.

Hâzimî, el-Emâkin ev Me’ttefeka lafzuh ve'ftereka müsemmâh mine’l-emkine, nşr. Hamed el-Câsir, Dımaşk: Dârü'l-Yemâme, 1415.

Himyerî, İbn Abdülmün'im, er-Ravzü’l-mi'târ fî haberil-aktâr, nşr. İhsan Abbas, Beyrut: Müessesetü Nâsır li's-sekāfe, 1980.

İbn Abdülber en-Nemerî, Câmiu beyâni'l-ilm ve fazlih, nşr. Şuayb el-Arnaût, Beyrut: Müessesetü’r-risâle, 2008.

İbn Abdülber en-Nemerî, el-İstîâb fî ma'rifeti'l-ashâb, nşr. Ali M. el-Bicâvî, I-IV, Beyrut: Dârü’l-cîl, 1992.

İbn Abdülhak el-Bağdâdî, Merâsıdüll-ıttılâ‘ alâ esmâil-emkine ve'l-bikā', I-III, Beyrut: Dârü'l-cîl, 1402.

İbn Asâkir, Târîhu Medîneti Dımaşk, nşr. Ömer b. Garâme el-Amrî, XLII, Beyrut: Dârü’lfikr, 1417/1996.

İbn Battâl, Şerhu Sahîhi'l-Buhârî, nşr. Ebû Temîm Yâsir b. İbrâhim, I-X, Riyad: Mektebetü’rRüşd, 2003.

İbn Ebû Şeybe, el-Musannef fi'l-ehâdîs ve'l-âsâr, nşr. Kemâl Yûsuf el-Hût, I-VII, Beyrut: Dârü’t-tâc, 1409/1989.

İbn Hacer el-Askalânî, ed-Dürerü'l-kâmine fî a'yâni'l-mieti's-sâmine, nşr. M. Abdülmuîd Hân, I-VI, Haydarâbâd: Dâiretü’l-maârifi'l-Osmâniyye, 1972.

İbn Hacer el-Askalânî, Fethu'l-bârî şerhu Sahîhil-Buhârî, nşr. M. Fuâd Abdülbâkī v.dğr., I-XIII, Beyrut: Dârü'l-ma'rife, 1379.

İbn Hacer el-Askalânî, Lisânül-Mîzân, nşr. Abdülfettâh Ebû Gudde, I-X, Beyrut: Dârü’lbeşâiri'l-İslâmiyye, 1423/2002.

İbn Hacer el-Askalânî, Tehzîbü't-Tehzîb, I-XII, Haydarâbâd: Dâiretü’l-maârifỉn-Nizâmiyye, 1325-27/1907-1909.

İbn Hibbân, es-Sikāt, I-IX, Haydarâbâd: Dâiretü'l-maârifi'l-Osmâniyye, 1393-99/1973-79.

İbn Hibbân, Sahîhu İbn Hibbân bi-tertîbi İbn Balabân, nşr. Şuayb el-Arnaût, I-XVIII, Beyrut: Müessesetürr-risâle, 1414/1993.

İbn Hişâm, es-Sîretün-nebeviyye, nşr. Mustafa es-Sekkā v.dğr., I-II, Kahire: Mektebetü ve matbaatü Mustafa el-Bâbî el-Halebî, 1375/1955.

İbn Kudâme, Muvaffakuddin, el-Mugnî, I-X, Kahire: Mektebetü'l-Kahire, 1968.

İbn Kurkūl, Metâliu'l-envâr alâ sıhâhi'l-âsâr, nşr. Vizâretüll-evkāf ve'ş-şuûni'l-İslâmiyye, I-VI, Katar: Dârü'l-felâh, 1433/2012.

İbn Şebbe, Târîhu'l-Medîneti'l-münevvere, nşr. Fehîm M. Şeltût, I-IV, Cidde: Dâru'lİsfehânî, 1973.

İbn Teymiyye, Takıyyüddin, Mecmûu fetâvâ, nşr. Abdurrahman b. Muhammed b. Kāsım, Medine: Mecmeu'l-Melik Fehd, 1995.

İbn Zebâle, Ahbârü'l-Medîne, nşr. Salâh Abdülazîz Zeyn Selâme, Medine: Merkezü buhûs ve dirâsâti'l-Medîneti'l-münevvere, 1424/2003. 
İbnü'l-Esîr, Mecdüddin, Câmiu'l-usûl fî ehâdîsìr-Resûl, nşr. Abdülkādir el-Arnaût, I-XII, Beyrut: Mektebetü'l-Halvânî, 1389-92/1969-72.

İbnü'l-Esîr, Mecdüddin, en-Nihâye fî garîbi'l-hadîs ve'l-eser, nşr. Halîl b. Me’mûn, I-II, Beyrut: Dârü'l-ma'rife, 2011.

İbnü'l-Müneyyir, el-Mütevârî alâ ebvâbi'l-Buhârî, nşr. Ali Hasan Ali Abdülhamîd, Beyrut: el-Mektebü'l-İslâmî, Amman: Dâru Ammâr, 1411/1990.

İbnü’n-Neccâr el-Bağdâdî, ed-Dürretü̉s-semîne fî ahbâri'l-Medîne, nşr. Hüseyin M. Ali Şükrî, Beyrut: Dârü'l-Erkam b. Ebü'l-Erkam, t.y.

İfrenî, Fethu'l-mugīs bi-hükmi'l-lahn fi'l-hadîs, nşr. Abdülmecîd Hayâlî, Beyrut: Dârü’lkütübi'l-ilmiyye, 1424/2003.

Kādî İyâz, el-İlmâ' ilâ ma'rifeti usûlirr-rivâye ve takyîdi's-semâ', nşr. Seyyid Ahmed Sakr, Kahire: Dârü't-türâs, 1389/197o.

Kādî İyâz, İkmâlü'l-Mu'lim bi-fevâidi Müslim, nşr. Yahyâ İsmâil, I-IX, Mansûre: Dârü'lvefâ, 1419/1998.

Kādî İyâz, Meşâriku'l-envâr alâ sıhâhi'l-âsâr, I-II, Tunus: el-Mektebetü'l-atîka, Kahire: Dârü't-türâs, 1978.

Kastallânî, Ahmed b. Muhammed, İrşâdü̉s-sârî li-şerhi Sahîhi'l-Buhârî, I-X, Bulak: elMatbaatü'l-Emîriyye, 1323.

Kuzudişli, Bekir, Şîa ve Hadis: Başlangıcından Kütüb-i Erbaa'ya Hadis Rivayeti ve İsnad, İstanbul: Klasik Yayınları, 2017.

Mâlik b. Enes, el-Muvatta', nşr. M. Fuâd Abdülbâkī, I-II, Beyrut: Dâru ihyâi't-türâsi'lArabî, 1985.

Matarî, Cemâleddin, et-Ta'rîf bimâ enseti'l-hicre min meâlimi Dâri'l-hicre, nşr. Süleyman er-Rahîlî, Riyad: Dâretü’l-Melik Abdülazîz, 1426/2005.

Mâzerî, el-Mu'lim bi fevâidi Müslim, nşr. Muhammed eş-Şâzelî en-Neyfer I-III, Tunus: Beytü’l-hikme, 1987.

Miras, Kâmil, “Âir”, İslâm Türk Ansiklopedisi, I-II, İstanbul: Âsâr-1 İlmiye Kütüphanesi Neşriyat1, 1941.

Miras, Kâmil, Sahîh-i Buhârî Muhtasarı Tecrîd-i Sarîh Tercemesi ve Şerhi, VII, Ankara: DİB Yayinlar1, 1982.

Muhammed Mahlûf, Şeceretün-nûri'z-zekiyye fî tabakātil-Mâlikiyye, nşr. Abdülmecîd Hayâlî, I-II, Beyrut: Dârüll-kütübi'l-ilmiyye, 2003.

Mühelleb b. Ebû Sufre et-Temîmî, Muhtasarün-nasîh fî tehzîbi'l-Kitâbil-Câmii’s-sahîh, nşr. Ahmed b. Fâris es-Sellûm, I-IV, Riyad: Dârü’t-tevhîd, Dâru Ehli’s-sünne, 1430/2009.

Münâvî, Muhammed b. İbrâhim, Keş̧üll-menâhîc ve't-tenâkīh fî tahrîci ehâdîsi'l-Mesâbîh, nşr. Muhammed İshak Muhammed İbrâhim I-V, Beyrut: ed-Dârü'l-Arabiyye li'lmevsûât, 2004 .

Müslim b. Haccâc, Sahîhu Müslim, nşr. M. Fuâd Abdülbâkī, I-V, Kahire: Dârü’l-hadîs, 1997.

Nesâî, es-Sünenü’l-kübrâ, nşr. Hüseyin Abülmün'im eș-Şiblî I-X, Beyrut: Müessesetü’rrisâle, 1421/2001. 
Nevevî, el-Minhâc şerhu Sahîhi Müslim b. el-Haccâc, I-IX, Beyrut: Dâru ihyâi't-türâsi'lArabî, 1392/1972.

Nevevî, Tehzîbü'l-esmâ’ ve'l-lugāt, I-IV, Beyrut: Dârü'l-kütübi'l-ilmiyye, t.y.

Ögüt, Salim, "Ehl-i Hadîs", DİA, 1994, X, 510.

Öğ̈̈t, Salim, “Harem”, DİA, 1997, XVI, 127-132.

Örenç, Aşır, Hadislerde Kutsal Mekân Algısı (doktora tezi), Süleyman Demirel Üniversitesi Sosyal Bilimler Enstitüsü, 2013.

Özben, Zübeyde, Hadislerde Geçen Yer İsimleri (Buhârî Özelinde) (yüksek lisans tezi), Marmara Üniversitesi Sosyal Bilimler Enstitüsü, 2011.

Özsoy, Abdulvahap, Buhârî Nüshaları ve Nüsha Farklılılarının Mahiyeti Üzerine, Kayseri: Fenomen Yayınları, 2016.

Polat, Salahattin, Metin Tenkidi, İstanbul: MÜİF Yayınları, 2010.

Rif'at Fevzî Abdülmuttalib, Sahîfetü Alî b. Ebî Tâlib, Kahire: Dârü’s-selâm, 1406/1986.

Rifâî, Sâlih b. Hâmid b. Saîd, el-Ehâdîsüll-vâride fî fezâili’l-Medîne, Medine: Dârül-Hudayrî, 1413/1992.

Saîd b. Mansûr, Sünenü Saîd b. Mansûr, nşr. Habîbürrahman el-A'zamî, I-II, Bombay: Dârü’s-Selefiyye, 1982.

Sehârenpûrî, Halîl Ahmed, Bezlül-mechûd fî halli Ebî Dâvûd, nşr. M. Zekeriyyâ b. Yahyâ el-Kandehlevî, I-XX, Beyrut: Dârü'l-kütübi'l-ilmiyye, 2008.

Sehâvî, Şemseddin, et-Tuhfetü’l-latîfe fî târîhi'l-Medîneti’şş̧erîfe, I-II, Beyrut: Dârü’l-kütübi'l-ilmiyye, 1414/1993.

Semhûdî, Vefâüll-vefâ bi-ahbâri dâri'l-Mustafâ, nşr. M. Muhyiddin Abdülhamîd, I-IV, Beyrut: Dâru ihyâi't-türâsi'l-Arabî, 1997.

Serahsî, el-Mebsût, nşr. Halil Muhyiddin el-Meys, I-XXX, Beyrut: Dârü’l-fikr, 2000.

Sezgin, Fuat, Buhârînin Kaynakları Hakkında Araștırmalar, İstanbul: İbrahim Horoz Basimevi, 1956.

Süheylî, Abdurrahman b. Abdullah, er-Ravzü'l-ünüf fî şerhiss-Sîreti’n-nebeviyye li’bn Hişâm, nşr. Ömer Abdüsselâm es-Selâmî, I-VII, Beyrut: Dâru ihyâi't-türâsi'l-Arabî, 2000.

Süyûtî, Tedrîbürr-râvî fî şerhi Takrîbìn-Nevâvî, nşr. M. Avvâme, I-V, Medine: Dârü’l-yüsr Cidde: Dârü'l-minhâc, 1437/2016.

Şehrî, Melfî b. Hasan, Mecmûu hadîsî fîhi: Lahnürr-ruvât ve eserühî fî rivâyeti’l-hadîs, Kahire: Dârü'l-muhaddisîn, 1429/2008.

Şevkī Ebû Halîl, Atlasül-hadîsin-nebevî mine'l-kütübi’s-Sihâhi’s-sitte, Dımaşk: Dârü'l-fikr, 2005.

Şinkītî, M. Hıdır, Kevserü'l-meâni'd-derârî fî keş̧i habâyâ Sahîhi'l-Buhârî, I-XIV, Beyrut: Müessesetü’r-risâle, 1415/1995.

Şürrâb, M. M. Hasan, el-Meâlimü'l-esîre fi’s-sünne ve’s-sîre, Dımaşk: Dârü’l-kalem, 1411/1991.

Taberânî, el-Mu'cemü'l-evsat, nşr. Târık b. İvazullah - Abdülmuhsin b. İbrâhim, Kahire: Dârü'l-Haremeyn, 1415/1995. 
Taberânî, el-Mu'cemü'l-kebîr, nşr. Hamdî b. Abdülmecîd es-Selefî, I-XXV, Kahire: Mektebetü İbn Teymiyye, 1994.

Tahâvî, Şerhu meâni'l-âsâr, nşr. M. Zührî en-Neccâr - M. Seyyid Câdelhak, I-V, Beyrut: Âlemü'l-kütüb, 1414/1994.

Tayâlisî, el-Müsned, nşr. Muhammed b. Abdülmuhsin et-Türkî, I-IV, Cîze: Dâru Hecer, 1419-20/1999.

Tirmizî, el-Câmiu’s-sahîh: Sünenü̈t-Tirmizî, nşr. Ahmed M. Şâkir v.dğr., I-V, Kahire: Mektebetü ve matbaatü Mustafa el-Bâbî el-Halebî, 1395/1975.

Toksarı, Ali, “Kutbüddin el-Halebî”, DİA, 2002, XXVI, 484.

Watt, William Montgomery, "al-Madina”, The Encyclopaedia of Islam (EI [İng.]), I-XI, Leiden: E. J. Brill, 1954-2002.

Ya'kūbî, el-Büldân, nşr. M. Emîn Dannâvî, Beyrut: Dârü’l-kütübi’l-ilmiyye, 1422/2002.

Yâkūt el-Hamevî, Mu'cemü'l-büldân, I-VII, Beyrut: Dâru Sâdır, 1995.

Yâkūt el-Hamevî, el-Müşterik vaz'an el-müfterik suk'an, Beyrut: Âlemü'l-kütüb, 1406/1986.

Yllmaz, Nuray, İslâm Hukuku Açısından Mekke ve Medine Haremi (doktora tezi), Marmara Üniversitesi Sosyal Bilimler Enstitüsü, 2016.

Zehebî, Siyeru a'lâmi’n-nübelâ', nşr. Şuayb el-Arnaût, I-XXV, Beyrut: Müessesetü’r-risâle, 1401-1405/1981-85.

Zemahşerî, el-Cibâl ve’l-emkine ve’l-miyâh, nşr. Ahmed Abdüttevvâb, Kahire: Dârü’l-fazîle, 1999.

Zerkeşî, Bedreddin, I'lâmü's-sâcid fî ahkâmi'l-mesâcid, nşr. Ebü'l-Vefâ Mustafa el-Merâgī, Kahire: el-Meclisü'l-a'lâ li'ş-şüûni'l-İslâmiyye, 1996.

Ziriklî, el-A 'âm, I-VIII, Beyrut: Dârü'l-ilm li’l-melâyîn, 2002.

Ziyâeddin el-Makdisî, el-Ehâdîsü'l-muhtâre ev el-Müstahrec mine’l-ehâdîsil-muhtâre mimmâ lem yuhrichü'l-Buhârî ve Müslim fî Sahîhayhimâ, nşr. Abdülmelik b. Abdullah b. Dehîş, I-XIII, Beyrut: Dâru Hıdır, 1420/20oo.

http://www.taibanet.com/showthread.php?t=2039 (erişim: 15.10.2017) 


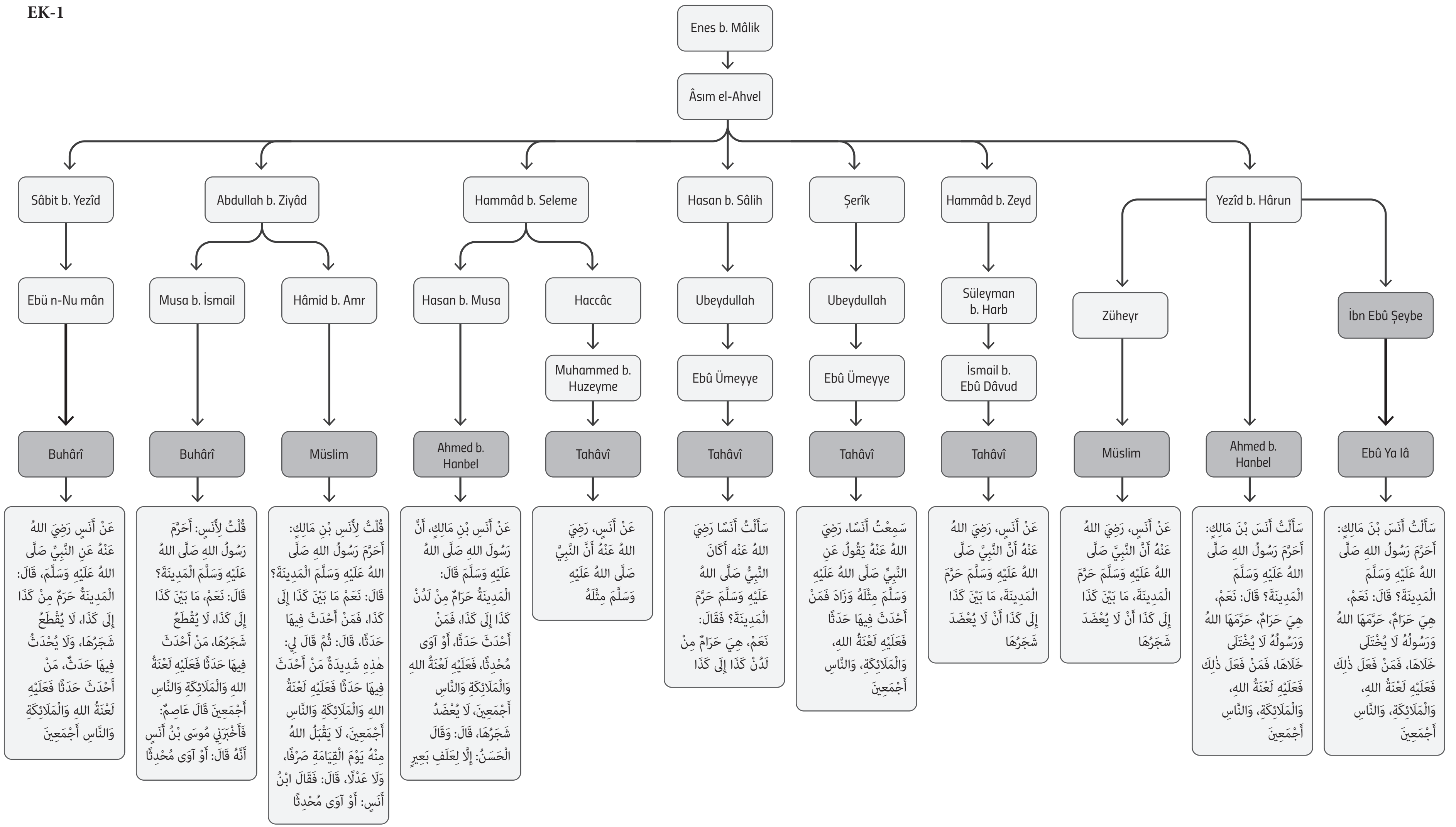




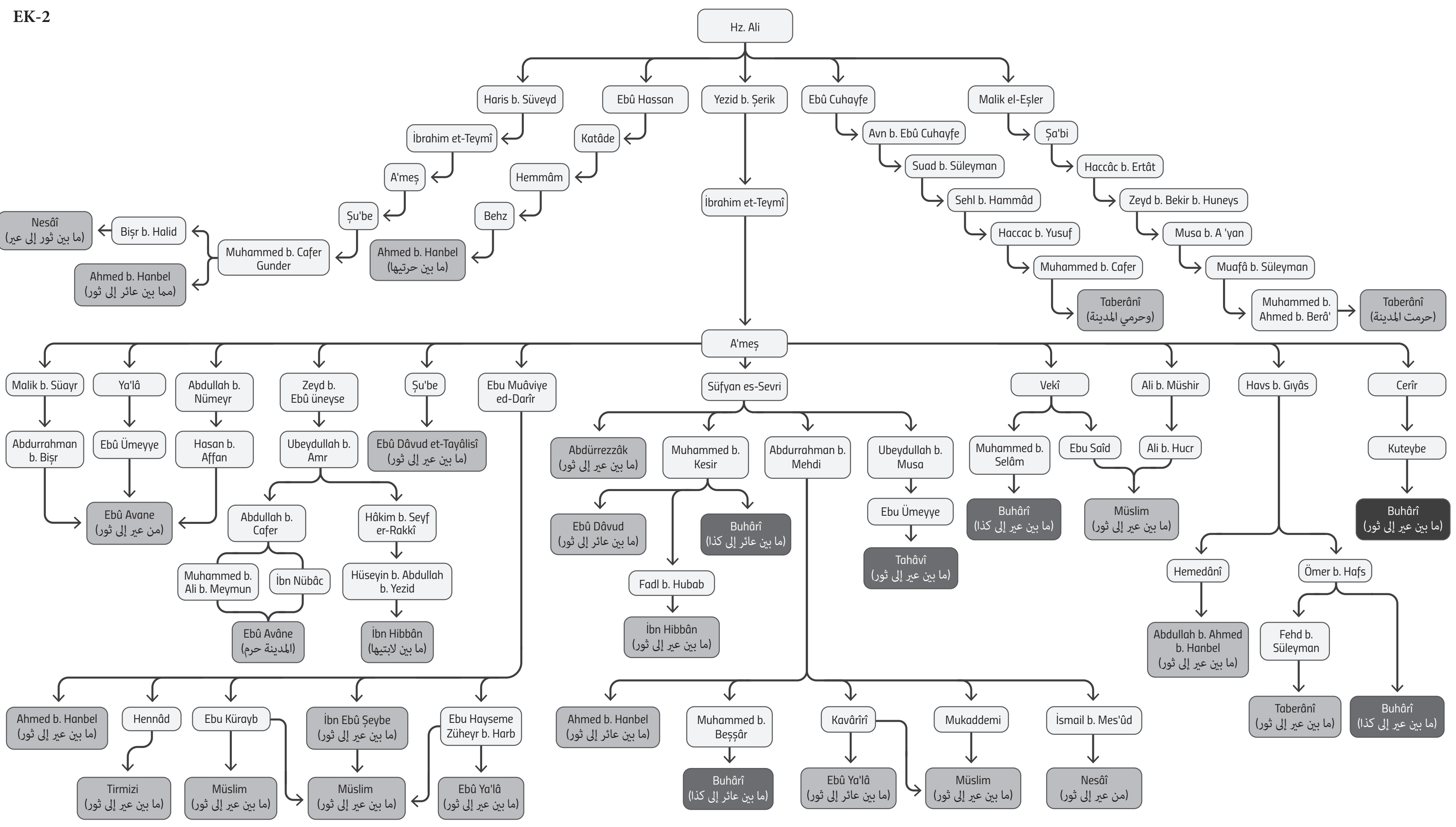




\section{Determination of Medina Haram Region: A Disputed Narration in Șạ̣ịh al-Bukhärī}

Some prophetic traditions ( hadith) express that Medina is a haram region, similar to Mecca. A majority of them do not specify the boundaries of Medina's haram region, citing only geographical formations like mountains and stony areas. According to a tradition in the șahîfa of 'Ali b. Abū Țālib, however, 'Ayr/'Ā'ir and Thawr Mountains were clearly determined as the north-south boundaries of the region. This tradition has been criticized since the early period on the basis that Thawr Mountain was unknown to the inhabitants of Medina. Moreover, it was also argued that a particular part of the tradition - the part that contains Thawr Mountain - was added as a result of the transmitter's delusions. Al-Qāsim ibn Sallām and other scholars found the mention of Thawr in the tradition to be unsound, given the details that the inhabitants of the city did not know about the mountain.

It has been argued that, influenced by the criticism, some transmitters and scholars categorizing the tradition made some changes to the relevant parts of the tradition. Al-Bukhārī and his work, al-Jāmi al-șaḥihh, stand at the center of criticism. This article aims to examine criticism addressed to the transmitters of the tradition that determines the boundaries as 'Ayr and Thawr as well as to al-Bukhārī who included this tradition in his collection. It also hopes to locate the reflections of initial critiques on the tradition's text. Therefore, it aims at underlining the fact that, aside from certain (un)intended additions to the tradition's texts, some additions may have been intended to compensate for critiques of the texts.

First, the article explores whether the mountains 'Ayr and Thawr actually exist in Medina based on geographic sources and studies of the city of Medina. Indeed, we understand that two small mountains do exist - one of them is to the south of the city with the name 'Ayr and the second one stands behind Mount Uhud, named Thawr. Then the article outlines the scholars who criticized the tradition and their arguments in chronological order. These critiques could be due to several factors, including the small size of Thawr, the reputation of Mount Uhud and the existence of another small mountain named Thawr in Mecca. These scholars' suggestion that the mountain mentioned is Mount Uhud instead of Thawr does not seem to be accurate, due to the fact that the transmission has flaws in its isnād; it does not appear in the sound collections of prophetic traditions and it remains marginal to other transmissions.

When we compare all the chains of transmissions, including the haram status of Medina, some chains are recorded vaguely in the form of "kadha". Some scholars explain this difference by memorization deficiencies on behalf of transmitters. Some of them, on the other hand, suggest that the transmitters and collectors of prophetic traditions made intentional changes in response to critiques.

We locate this vagueness only in al-Bukhārîss work. The transmitters he received from were criticized, as was he, for leaving the second boundary blank and replacing it with the word "kadhā". When we contextualize the transmission chains through the light of biographical dictionaries, the transmitters seem not to have 
made any changes to the tradition during the process of transmission. Therefore, the critiques are attributed to al-Bukhārī. In addition, al-Bukhārìs work notes that the form of this tradition with Thawr is incorrect. However, Sahin in includes this tradition with Thawr, which could mean that he would not make any changes to the text of the tradition based on this note. Indeed, some scholars such as Ibn Hajar try to neutralize the critiques by emphasizing this fact. The accounts on diverging information based on various copies of al-Bukhārỉs work manifest that defending al-Bukhārī from the phrases including Thawr is inaccurate. They also indicate that some transmitters/editors of al-Bukhārî̀s work made some changes to the related section. Someone may think that al-Bukhārī made the change originally because his work quotes it in the form of "kadhä", contrary to other tradition cataloguers, despite their mutual transmitter sources and because al-Bukhārī states openly that the use of the word Thawr is incorrect. However, various copies of al-Bukhārīs work have diverging texts on the related part, leading us to approach the critiques of al-Bukhārī with caution. Initial critiques of the tradition and al-Bukhārî̀s opinion might have influenced the later copy editors and they might have made some changes to the related section. The accounts relate that some copies left the place of Thawr blank and some others crossed out the word Thawr. This article discusses the possibility of changes by later copy editors after the composer al-Bukhārī to the relevant section of the tradition.

We can argue that the copy editors of Șahinh made changes to the text of the tradition and the differences in the tradition in various copies could be due to the editors' alterations. However, we are not sure whether this alteration intended to clarify a vague point and repeat a blank section, or whether it intended to make a section ambiguous because of the critiques to the transmission of the second boundary and al-Bukhārìss opinions on the subject. This latter possibility is supported by certain examples of editors' alterations on al-Bukhārìs text in order to correct or complete it, phrases on their open changes on the word Thawr in the tradition in the șahîfa as well as by some points for which al-Bukhārīs notes were applied to the text. Some other works stating that clear boundaries were made ambiguous also support this argument. According to this, al-Bukhārī made no change to the text of the tradition and it was, in fact, the copy editors who added the word " $k a d h a \vec{a}$ ". Besides, various answers appear to the question why certain manuscripts of Bukhärìs work record Thawr as the second boundary. If the later editors made an alteration at this point, we would expect them to do the same thing throughout the entirety of the transmissions. First, manuscripts that mention the second boundary as "kadhä" rarely mention Thawr with a clear signifier of boundary. Therefore, it has been suggested that some editors may have missed it. In addition, while one source records the boundary as blank in a manuscript, another source reports it as Thawr in the same manuscript. It seems probable that an editor left a blank space, which other editors filled in with Thawr with the help of notes in other sources.

Ultimately, it seems that Șahin has survived to us through alterations by alBukhārī, who included the tradition in his work, or by later editors as a result of the critiques of some scholars, principally Qāsim b. Sallām. Some critiques of the commentators who tried to bring extreme interpretations to the transmission 
were influential. Editors were in some way certainly involved in the process of some alterations of the tradition's transmission. Most likely, they changed the boundary, which was mentioned clearly in Sahīh al-Bukhärī, to an ambiguous form. As for al-Bukhārī, he does not seem to have made a clear alteration to the text.

By looking at similar examples in the literature of prophetic traditions, we can trace the influence of critiques at various stages, such as transmissions, records on books, commentaries and reproductions of books and on the texts of traditions. Studies of this sort will bring more stable ground for discussions on the reasons for differences in manuscripts, the process of transmission of works, the attitudes of transmitters/cataloguers and al-Bukhārī and his work.

Keywords: Medina, Thawr, al-Bukhārī, al-Jāmi‘ al-ṣaḥịh, ḥadīth criticism, alterations of transmitters. 
